\title{
Carbapenem-Sparing Strategies for ESBL Producers: When and How
}

\author{
Ilias Karaiskos * (D) and Helen Giamarellou \\ Department of Internal Medicine-Infectious Diseases, Hygeia General Hospital, 15123 Athens, Greece; \\ e.giamarellou@hygeia.gr \\ * Correspondence: ikaraiskos@hygeia.gr; Tel.: +30-210-686-7946; Fax: +30-210-686-7377
}

Received: 29 December 2019; Accepted: 3 February 2020; Published: 5 February 2020

\begin{abstract}
Extended spectrum $\beta$-lactamase (ESBL)-producing bacteria are prevalent worldwide and correlated with hospital infections, but they have been evolving as an increasing cause of community acquired infections. The spread of ESBL constitutes a major threat for public health, and infections with ESBL-producing organisms have been associated with poor outcomes. Established therapeutic options for severe infections caused by ESBL-producing organisms are considered the carbapenems. However, under the pressure of carbapenem overuse and the emergence of resistance, carbapenem-sparing strategies have been implemented. The administration of carbapenem-sparing antibiotics for the treatment of ESBL infections has yielded conflicting results. Herein, the current available knowledge regarding carbapenem-sparing strategies for ESBL producers is reviewed, and the optimal conditions for the "when and how" of carbapenem-sparing agents is discussed. An important point of the review focuses on piperacillin-tazobactam as the agent arousing the most debate. The most available data regarding non-carbapenem $\beta$-lactams (i.e., ceftolozane-tazobactam, ceftazidime-avibactam, temocillin, cephamycins and cefepime) are also thoroughly presented as well as non $\beta$-lactams (i.e., aminoglycosides, quinolones, tigecycline, eravacycline and fosfomycin).
\end{abstract}

Keywords: ESBLs; piperacillin-tazobactam; carbapenem-sparing treatment; cefepime; fosfomycin; urinary tract infection

\section{Introduction}

The spread of extended spectrum $\beta$-lactamase (ESBL)-producing bacteria has increased the last two decades in the hospital setting as well as in the community, emerging as a serious threat of public health [1]. In particular, infections caused by antimicrobial-resistant Escherichia coli proportionally contributed the most to the burden of antimicrobial resistance in Europe, both as number of cases and number of attributable deaths [2]. The population-weighted mean rates of the third-generation cephalosporin resistance in 2018 were $13.1 \%$ and $31.7 \%$ for E. coli and Klebsiella pneumoniae isolates, respectively, in the EU and the European Economic Area [2]. ESBLs are enzymes that confer resistance to most beta-lactam antibiotics, including third-generation cephalosporins and monobactams, and they are often seen in combination with other resistance mechanisms, causing multidrug resistance [3]. The majority of ESBLs belong to Ambler class $A$ and include the sulfhydryl reagent variable $\beta$-lactamase (SHV), Temoniera $\beta$-lactamase (TEM) and cefotaxime-M $\beta$-lactamase (CTX-M) types [3]. Infections caused by ESBL-producing Enterobacterales (ESBL-PE) are associated with increased mortality rates, prolonged hospital stays and increased costs [4]. Most clinical factors associated with colonization and infection with ESBL-producing organisms involve healthcare exposure, such as hospitalization, residence in a long-term care facility, hemodialysis use and presence of an intravascular catheter [5,6]. Risk factors for community-acquired infections include recent antibiotic therapy, use of corticosteroids, and the presence of a percutaneous feeding tube as well as international travel $[7,8]$. Carbapenems have been considered the "gold standard" treatment 
for the treatment of ESBL-PE and have been associated with improved outcomes, even when in vitro activity to other $\beta$-lactams is exhibited [9]. These findings cannot be extrapolated to all patients, as a considerable amount of literature has been published on the use of $\beta$-lactams/ $\beta$-lactamase inhibitor combinations (BLBLI) and specifically piperacillin-tazobactam [10-13]. In addition, the implementation of carbapenem-sparing strategies has also been applied in ESBL infections in order to combat the overuse of carbapenems and to facilitate antibiotic stewardship programs [14-17].

The current review is focused on the current state of evidence regarding carbapenem-sparing antibiotic options including non-carbapenem $\beta$-lactams as well as non $\beta$-lactams options for the treatment of ESBL-PE infections. A narrative review of relevant studies was conducted using the PubMed/MEDLINE, Scopus and Web of Science databases (from 1970 up to January 2020). The keywords used were ESBL, extended spectrum $\beta$-lactamases, carbapenem-sparing agents, bacteremia, septic shock, non b-lactams, carbapenems, meropenem, imipenem-cilastatin, ertapenem, $\beta$-lactams/ $\beta$-lactamase inhibitor combinations, piperacillin-tazobactam, ceftolozane-tazobactam, ceftazidime-avibactam, fosfomycin, tigecycline, eravacycline, aminoglycosides and quinolones. Information regarding empiric and definitive therapy of ESBL infections were included and clinical studies comparing the efficacy of carbapenem sparing agents to carbapenems were prioritized. In depth analysis focusing on piperacillin-tazobactam treatment for ESBL infections was covered as this agent has accumulated studies and appears to arouse the greatest debate. Evidence on non $\beta$-lactams (i.e., fosfomycin, tigecycline, eravacycline, aminoglycosides and quinolones) is thoroughly discussed, and suggestions on their proper use are indicated.

\section{Piperacillin-Tazobactam}

It is clear that piperacillin-tazobactam (PTZ) among non-carbapenem $\beta$-lactams represents the most interesting alternative to carbapenems in the treatment of infections causes by ESBL-PE, as well as for de-escalating carbapenems [18]. Despite the fact that a high percent of ESBL isolates demonstrate in vitro susceptibility to PTZ (current break point according to European Committee on Antimicrobial Susceptibility Testing (EUCAST) $\leq 8 \mathrm{mg} / \mathrm{L}$, and to Clinical \& Laboratory Standards Institute (CLSI) $\leq 16 \mathrm{mg} / \mathrm{L}$ ), the significance of PTZ for treating ESBL-PE has remained cloudy. Tazobactam by itself is a potent $\beta$-lactamase inhibitor. However, Gram-negative bacteria have the ability to produce concomitantly multiple ESBLs and AmpC $\beta$-lactamases, as well as possess other resistance mechanisms such as porin mutations and efflux activation, diminishing the activity of PTZ. On the other hand, tazobactam is influenced by the "inoculum effect" [18].

The clinical studies comparing the efficacy of PTZ versus carbapenems in infections caused by ESBL-PE are depicted in Table 1 [10-13,19-30]. Most comparative studies of PTZ versus carbapenems are retrospective and difficult to be evaluated because of several disagreements [11-13,19-22,24,25,27-30]. Rodríguez-Baño et al. [10] in 2012 conducted a post hoc analysis of patients with blood stream infection (BSI) due to ESBL-PE derived from 6 published prospective cohorts in Spain. Patients treated either with an active in vitro BLBLI (i.e., amoxicillin-clavulanic acid (AMC) and PTZ) or a carbapenem were compared in 2 cohorts: the empirical therapy cohort (ETC) with 103 patients (AMC 37, PTZ 35, carbapenem 31) and the definitive therapy cohort (DTC) with 174 patients (AMC 36, PTZ 18, carbapenem 120). E. coli was isolated in $100 \%$, the source of bacteremia being in $70 \%$ urinary or biliary. In $13 \%$, ICU admission at infection onset was necessary, pointing out that most patients were not critically ill. At day 30, mortality rates in the ETC were $9.7 \%$ vs. $19.4 \%$ and in the DTC $9.3 \%$ vs. $16.7 \%$ for those given BLBLI and carbapenems respectively (pNS). No association between BLBLI empirical therapy or definitive therapy and increased mortality was observed [10]. Despite the equal clinical validity between the administered antibiotics, the following points seem to compromise the results: (a) only E. coli infections were treated, whereas no K. pneumoniae isolates with bla $a_{\mathrm{SHV}}$ production, mostly resistant to tazobactam inhibition by definition, were included; (b) "low inoculum" infections (urinary and biliary tract) were mostly treated. It should be pointed out that when the MIC to PTZ was $\leq 4 \mathrm{mg} / \mathrm{L}$ mortality was $4.5 \%$, mounting to $23 \%$ in the case of MIC $\geq 8 \mathrm{mg} / \mathrm{L}$. Based on their results, Rodríguez-Baño et al. [10] suggested that PTZ should be given with safety only in "low inoculum" infections and whenever the MIC is $\leq 4 \mathrm{mg} / \mathrm{L}$ at a dosage schedule of $4.5 \mathrm{~g}$ every $6 \mathrm{~h}$. 
In the effort to evaluate the efficacy of BLBLI versus carbapenems in patients with a non-urinary source of ESBL-PE bacteremia, Ofer-Friedman et al. [11] performed a multicenter, multinational efficacy analysis from 2008 to 2012 comparing outcomes in patients given a carbapenem (69) versus those treated with PTZ (10). Despite the fact that PTZ was numerically connected with increased 30-day mortality ( $60 \%$ vs. $34 \%$ ), results were not statistically significant $(p=0.1)$ probably because of the small sample size. However, in terms of 90-day mortality, therapy with PTZ was associated with increased mortality. Therefore, authors suggested carbapenems as superior therapy for ESBL-PE infections.

Subsequently, a retrospective study including 92 BSI caused by cefotaxime non-susceptible $E$. coli and K. pneumoniae (producing ESBL or AmpC $\beta$-lactamases) has been reported [12]. Definitive monotherapy with a carbapenem (23) (mostly meropenem) was compared to a BLBLI (24) (mostly PTZ with MIC of $\leq 4 \mathrm{mg} / \mathrm{L}$ in $70.7 \%$ and $8 \mathrm{mg} / \mathrm{L}$ in $29.3 \%$ ). Comparable outcomes were observed in patients given definitive therapy in terms of all-cause mortality, resolution of systemic Inflammatory Response Syndrome (SIRS), length of stay or BSI relapse, without significant differences in reinfections or colonization with multi-drug resistant (MDR) Gram-negatives or even Clostridium difficile infection. Harris et al. [12] concluded that "despite the fact that directed therapy with a BLBLI, when susceptibility is proven, may represent an appropriate carbapenem sparing option, larger studies, adequately powered to detect differences in mortality before such a strategy can be recommended, are required".

Contrary to the reported studies, Tamma et al. [20] in a retrospective study evaluated PTZ (103 patients) in comparison to a carbapenem (110 patients) in the treatment of 213 patients with ESBL BSI caused by E. coli, K. pneumoniae, Klebsiella oxytoca and Proteus mirabilis. A MIC to PTZ $\leq 16 \mathrm{mg} / \mathrm{L}$ was a prerequisite for inclusion in the study. The primary outcome was time to death from the first day of BSI. After the first positive blood culture, there were 17 (17\%) deaths in the PTZ group vs. $9(8 \%)$ in the carbapenem group. Covariates independently associated with a higher risk of death by day 14 were higher Pitt bacteremia score and ICU-level care needed on day 1 of BSI. The adjusted risk of death was 1.92 times higher for patients treated empirically with PTZ. In the final conclusion of the study, authors stated that "until more definitive studies are performed, for patients at high risk of invasive ESBL infections, early carbapenem therapy should be considered". However, a major issue not commented was source control of catheter-related infections as a cause of bacteremia in 43.7\% of the included patients [20].

One year later, Gutiérrez-Gutiérrez et al. [13] published an international observational study (called INCREMENT study), investigating the possibility of replacing carbapenems with BLBLI for treating BSI due to ESBL-PE. The main outcomes were clinical response, as cure/improvement at day 14 and 30-day mortality. Two groups of patients were included-(a) 365 in an empirical therapy cohort (PTZ in 123 cases and a carbapenem in 195) and (b) 601 in a targeted therapy cohort (PTZ in 60 and a carbapenem in 509)—-therefore comprising, to date, the largest study cohort. The 14-day cure/improvement rates were, in the first cohort, $78.9 \%$ for carbapenems and $80 \%$ for BLBLIs $(p=0.81)$, with mortality rates of $20 \%$ vs. $17.6 \%(p=0.3)$, and in the second cohort $90.2 \%$ and $85.5 \%(p=0.22)$ with mortality rates of $9.8 \%$ vs. $13.9 \%(p=0.28)$ respectively. The authors concluded that "active in vitro BLBLIs are not inferior to carbapenems for the treatment of BSI due to ESBL-PE in different clinical scenarios", suggesting that BLBLIs may be useful alternatives to carbapenems if used in appropriate doses [13]. An important issue raising doubts of PTZ efficacy is the diminished activity of tazobactam in the presence of a high burden of bacteria with MICs frequently near the breakpoints, whereas the MICs of carbapenems (except ertapenem) are usually several dilutions below the breakpoints rendering, at least from the pharmacokinetic/pharmacodynamic (PK/PD) aspect, the carbapenems advantageous [31]. On the other hand, the type of pathogens seemed to be influential in mortality rates, since K. pneumoniae was independently associated with higher death rate than E. coli both in the targeted and the global-therapy cohort [13]. Despite the fact that the INCREMENT data were the best available evidence to support the use of BLBLIs in carbapenem-sparing programs at the time of their publication, prospective randomized control trials to evaluate high-inoculum infections, severe infections as well as Enterobacterales infections with elevated MICs were requested [13]. 
Table 1. Clinical studies comparing the efficacy of piperacillin-tazobactam versus carbapenems in infections caused by ESBL-producing Enterobacterales [10-13,19-30].

\begin{tabular}{|c|c|c|c|c|c|c|c|c|c|}
\hline Study & $\begin{array}{l}\text { Country of Study } \\
\text { (Period of Study) }\end{array}$ & Study Design & $\begin{array}{l}\text { PTZ (n, Number } \\
\text { of Participants) }\end{array}$ & $\begin{array}{c}\text { Carbapenems ( } n, \\
\text { Number of } \\
\text { Participants) } \\
\end{array}$ & Organism(s) & Site of Infection & $\begin{array}{l}\text { Severity of Illness at } \\
\text { Infection Onset }\end{array}$ & $\begin{array}{l}\text { Outcome (PTZ vs } \\
\text { Carbapenems) }\end{array}$ & Comments \\
\hline $\begin{array}{l}\text { Rodríguez-Baño } \\
\text { et al. a [10] }\end{array}$ & Spain (2001-2006) & $\begin{array}{l}\text { Post hoc analysis } \\
\text { of } 6 \text { prospective } \\
\text { cohorts }\end{array}$ & $\begin{array}{c}\text { Empiric: } n=35 \\
\text { Definitive: } n=18\end{array}$ & $\begin{array}{l}\text { Empiric: } n=31 \\
\quad \text { Definitive: } \\
\quad n=120\end{array}$ & Escherichia coli $(100 \%)$ & $\begin{array}{c}\text { BSI }(100 \%) \\
\text {-urinary or biliary } \\
\text { (70\%) }\end{array}$ & $\begin{array}{c}\text { ICU: } 13 \% \\
\text { Severe sepsis or shock: } \\
23 \%\end{array}$ & $\begin{array}{c}\text { 30-day mortality (empiric): } \\
10 \% \text { vs 19\% (ns) } \\
30-\text { day mortality } \\
\text { (definitive): } 9 \% \text { vs } 17 \% \text { (ns) }\end{array}$ & $\begin{array}{l}\text { No association between } \\
\text { either empirical or definitive } \\
\text { therapy with PTZ and } \\
\text { increased mortality }\end{array}$ \\
\hline Kang et al. [19] & Korea (2008-2010) & Retrospective & $n=36$ & $n=78$ & $\begin{array}{c}\text { E. coli }(68 \%) \\
\text { Klebsiella pneumoniae } \\
(32 \%)\end{array}$ & BSI $(100 \%)$ & NR & $\begin{array}{c}\text { 30-day mortality: } 22 \% \text { vs } \\
27 \%(\mathrm{~ns})\end{array}$ & $\begin{array}{l}\text { No difference between PTZ } \\
\text { and carbapenem treatment }\end{array}$ \\
\hline Tamma et al. [20] & USA (2007-2014) & Retrospective & $n=103$ & $n=110$ & $\begin{array}{c}\text { K. pneumoniae (68\%) } \\
\text { E. coli } \\
(31 \%) \\
\text { Proteus mirabilis }(1 \%)\end{array}$ & $\begin{array}{c}\text { BSI }(100 \%) \\
\text {-CRBSI }(46 \%) \\
\text {-UTI }(21 \%) \\
\text {-CIAI (17\%) } \\
\text {-Biliary }(9 \%) \\
\text {-pneumonia }(9 \%)\end{array}$ & $\begin{array}{c}\text { ICU: } 34 \% \\
\text { Neutropenia: } 15 \%\end{array}$ & $\begin{array}{c}\text { 14-day mortality: } 17 \% \text { vs } \\
8 \%(p<0.05) \\
\text { 30-day mortality: } 26 \% \text { vs } \\
11 \% \\
(p<0.01)\end{array}$ & $\begin{array}{l}\text { PTZ inferior to carbapenems } \\
\text { for the treatment of ESBL } \\
\text { bacteremia. Risk of death } \\
1.92 \text { times higher for patients } \\
\text { on empiric PTZ therapy }\end{array}$ \\
\hline $\begin{array}{l}\text { Ofer-Friedman } \\
\text { et al. [11] }\end{array}$ & $\begin{array}{l}\text { Multicenter (USA, } \\
\text { Israel) (2008-2012) }\end{array}$ & Retrospective & $n=10$ & $n=69$ & $\begin{array}{c}\text { E. coli } \\
(53 \%) \\
\text { K. pneumoniae }(28 \%) \\
\text { P. mirabilis }(19 \%)\end{array}$ & $\begin{array}{c}\text { BSI (100\%) } \\
\text {-pneumonia (34\%) } \\
\text {-SSTI (28\%) } \\
\text {-Biliary (17\%) } \\
\text {-cIAI (9\%) }\end{array}$ & $\begin{array}{l}\text { Rapid fatal condition } \\
\text { per McCabe score: } 39 \%\end{array}$ & $\begin{array}{c}\text { 30-day mortality: } 60 \% \text { vs } \\
34 \% \\
(p=0.10) \\
\text { 90-day mortality: } 80 \% \text { vs } \\
48 \% \\
(p=0.05) \\
\end{array}$ & $\begin{array}{l}\text { Therapy with PTZ was } \\
\text { associated with increased } \\
\text { 90-day mortality (adjusted } \\
\text { OR, 7.9. } p=0.03 \text { ) }\end{array}$ \\
\hline Harris et al. [12] & Singapore (2012-2013) & Retrospective & $n=24$ & $n=23$ & $\begin{array}{c}\text { E. coli } \\
(86 \%) \\
\text { K. pneumoniae (14\%) }\end{array}$ & $\begin{array}{l}\text { BSI }(100 \%) \\
\text {-UTI }(47 \%) \\
\text {-Biliary }(9 \%) \\
\end{array}$ & ICU: $15 \%$ & $\begin{array}{l}\text { 30-day mortality: } 8 \% \text { vs } \\
17 \% \text { (ns) }\end{array}$ & $\begin{array}{l}\text { No difference between PTZ } \\
\text { and carbapenem treatment }\end{array}$ \\
\hline $\begin{array}{l}\text { Gutiérrez-Gutiérrez } \\
\text { et al. a }{ }^{\text {[13] }}\end{array}$ & $\begin{array}{l}\text { INCREMENT } \\
\text { international project } \\
(2004-2013)\end{array}$ & Retrospective & $\begin{array}{l}\text { Empiric: } n=123 \\
\text { Definitive: } n=60\end{array}$ & $\begin{array}{l}\text { Empiric: } n=195 \\
\quad \text { Definitive: } \\
n=509\end{array}$ & $\begin{array}{c}\text { E. coli }(73 \%) \\
\text { K. pneumoniae }(19 \%)\end{array}$ & $\begin{array}{c}\text { BSI }(100 \%) \\
\text {-UTI }(45 \%) \\
\text {-Biliary }(12 \%)\end{array}$ & $\begin{array}{c}\text { ICU: } 11 \% \\
\text { Severe sepsis or shock: } \\
32 \%\end{array}$ & $\begin{array}{c}\text { 30-day mortality (empiric): } \\
18 \% \text { vs } 20 \% \text { (ns) } \\
30 \text {-day mortality } \\
\text { (definitive): } 10 \% \text { vs } 14 \% \\
\text { (ns) }\end{array}$ & $\begin{array}{l}\text { No association between } \\
\text { either empirical or definitive } \\
\text { therapy with PTZ and } \\
\text { increased mortality }\end{array}$ \\
\hline Ng et al. [21] & Singapore (2011-2013) & Retrospective & $n=94$ & $n=57$ & $\begin{array}{c}\text { E. coli } \\
(67 \%) \\
\text { K. pneumoniae }(33 \%)\end{array}$ & $\begin{array}{c}\text { BSI }(100 \%) \\
\text {-UTI (59\%) } \\
\text {-Biliary }(9 \%) \\
\text {-Pneumonia }(9 \%) \\
\text {-CIAI }(5 \%) \\
\text {-CRBSI }(4 \%)\end{array}$ & ICU: 9\% & $\begin{array}{l}\text { 30-day mortality: } 31 \% \text { vs } \\
30 \% \text { (ns) }\end{array}$ & $\begin{array}{l}\text { No difference between PTZ } \\
\text { and carbapenem treatment }\end{array}$ \\
\hline Gudiol et al. ${ }^{\mathrm{a}}[22]$ & Multicenter (2006-2015) & Retrospective & $\begin{array}{c}\text { Empiric: } n=44 \\
\text { Definitive: } n=12\end{array}$ & $\begin{array}{l}\text { Empiric: } n=126 \\
\quad \text { Definitive: } \\
n=234\end{array}$ & $\begin{array}{c}\text { E. coli }(74 \%) \\
\text { K. pneumoniae }(23 \%) \\
\text { K. oxytoca }(1.5 \%) \\
\text { Enterobacter cloacae } \\
(1.5 \%) \\
\end{array}$ & $\begin{array}{c}\text { BSI }(100 \%) \\
\text {-Primary }(53 \%) \\
\text {-CRBSI }(18 \%) \\
\text {-CIAI }(15 \%) \\
\text {-UTI }(7 \%) \\
\end{array}$ & $\begin{array}{c}\text { ICU: } 18 \% \\
\text { Septic shock: } 22 \% \\
\text { Hematological } \\
\text { neutropenic patients: } \\
100 \% \\
\end{array}$ & $\begin{array}{l}\text { 30-day mortality (empiric): } \\
21 \% \text { vs } 13 \% \text { (ns) } \\
30 \text {-day mortality } \\
\text { (definitive): } 6 \% \text { vs } 16 \% \text { (ns) }\end{array}$ & $\begin{array}{c}\text { PTZ appeared to have } \\
\text { similar efficacy to } \\
\text { carbapenems in } \\
\text { hematological neutropenic } \\
\text { patients } \\
\end{array}$ \\
\hline Seo et al. [23] & Korea (2013-2015) & Randomized trial & $n=33$ & $n=33$ & E. coli $(100 \%)$ & $\begin{array}{l}\text { UTI }(100 \%) \\
\text { BSI }(11 \%)\end{array}$ & Septic shock: $30 \%$ & $\begin{array}{c}\text { 28-day mortality: } 6.1 \% \text { vs } \\
6.1 \%(\mathrm{~ns})\end{array}$ & $\begin{array}{l}\text { PTZ appeared to have } \\
\text { similar efficacy to ertapenem } \\
\text { in UTIs }\end{array}$ \\
\hline
\end{tabular}


Table 1. Cont.

\begin{tabular}{|c|c|c|c|c|c|c|c|c|c|}
\hline Study & $\begin{array}{l}\text { Country of Study } \\
\text { (Period of Study) }\end{array}$ & Study Design & $\begin{array}{l}\text { PTZ (n, Number } \\
\text { of Participants) }\end{array}$ & $\begin{array}{c}\text { Carbapenems ( } n \\
\text { Number of } \\
\text { Participants) }\end{array}$ & Organism(s) & Site of Infection & $\begin{array}{l}\text { Severity of Illness at } \\
\text { Infection Onset }\end{array}$ & $\begin{array}{l}\text { Outcome (PTZ vs } \\
\text { Carbapenems) }\end{array}$ & Comments \\
\hline Yoon et al. [24] & Korea (2011-2013) & Retrospective & $n=68$ & $n=82$ & E. coli $(100 \%)$ & $\begin{array}{l}\text { UTI }(100 \%) \\
\text { BSI }(15 \%)\end{array}$ & $\begin{array}{c}\text { ICU: } 25 \% \\
\text { Septic shock: } 16 \%\end{array}$ & $\begin{array}{c}\text { In-hospital mortality: } \\
4.4 \% \text { vs } 13 \% \text { (ns) }\end{array}$ & $\begin{array}{l}\text { PTZ appeared to have } \\
\text { similar efficacy to ertapenem } \\
\text { in UTIs }\end{array}$ \\
\hline Ko et al. a [25] & Korea (2010-2014) & Retrospective & $n=41$ & $n=183$ & $\begin{array}{c}\text { E. coli }(66 \%) \\
\text { K. pneumoniae (34\%) }\end{array}$ & $\begin{array}{c}\text { BSI }(100 \%) \\
\text {-Primary }(24 \%) \\
\text {-CRBSI }(3 \%) \\
- \text {-UTI }(37 \%) \\
- \text {-IAI }(28 \%) \\
\end{array}$ & ICU: $33 \%$ & $\begin{array}{l}\text { 30-day mortality: } 6.3 \% \text { vs } \\
11.4 \%(\mathrm{~ns})\end{array}$ & $\begin{array}{l}\text { No difference between PTZ } \\
\text { and carbapenem treatment }\end{array}$ \\
\hline Harris et al. [26] & $\begin{array}{l}\text { International, } \\
\text { multicenter (2014-2017) }\end{array}$ & Randomized trial & $n=188$ & $n=191$ & $\begin{array}{c}\text { E. coli }(87 \%) \\
\text { K. pneumoniae }(13 \%)\end{array}$ & $\begin{array}{c}\text { BSI }(100 \%) \\
\text { - UTI }(61 \%) \\
\text {-CIAI }(16 \%) \\
\text {-CRBSI }(2 \%) \\
\text {-Pneumonia (3\%) } \\
\text {-Mucositis (5\%) } \\
\text {-SSTI }(1 \%)\end{array}$ & $\begin{array}{c}\text { ICU: } 7 \% \\
\text { Neutropenia: } 7 \%\end{array}$ & $\begin{array}{c}\text { 30-day mortality: } 12.3 \% \text { vs } \\
3.7 \%(p=0.90)\end{array}$ & $\begin{array}{l}\text { Definitive treatment with } \\
\text { PTZ compared with } \\
\text { meropenem did not result in } \\
\text { a non-inferior 30-day } \\
\text { mortality }\end{array}$ \\
\hline Benanti et al. [27] & USA (2008-2015) & Retrospective & $n=21$ & $n=42$ & E. coli $(100 \%)$ & $\begin{array}{c}\text { BSI }(100 \%) \\
\text { - cIAI }(40 \%) \\
\text {-UTI (10\%) } \\
\text {-CRBSI }(11 \%) \\
\text {-Pneumonia }(11 \%) \\
\text {-SSTI }(10 \%)\end{array}$ & $\begin{array}{c}\text { ICU: } 30 \% \\
\text { Neutropenia: } 89 \%\end{array}$ & $\begin{array}{c}\text { 14-day mortality: } 0 \% \text { vs } \\
19 \%(p=0.04)\end{array}$ & $\begin{array}{l}\text { Empiric treatment with PTZ } \\
\text { not associated with increased } \\
\text { mortality in patients with } \\
\text { hematologic malignancy }\end{array}$ \\
\hline John et al. [28] & USA (2014-2017) & Retrospective & $n=66$ & $n=51$ & $\begin{array}{c}\text { E. coli }(86 \%) \\
\text { K. pneumoniae }(14 \%)\end{array}$ & $\begin{array}{c}\text { BSI }(100 \%) \\
\text {-UTI }(73 \%) \\
\text {-cIAI }(19 \%) \\
\text {-Pneumonia (1\%) } \\
\end{array}$ & $\begin{array}{c}\text { ICU: } 38 \% \\
\text { Septic shock:17\% }\end{array}$ & $\begin{array}{c}\text { In-hospital mortality: 3\% } \\
\text { vs } 7.8 \%(\mathrm{~ns})\end{array}$ & $\begin{array}{l}\text { PTZ appeared to have } \\
\text { similar efficacy to } \\
\text { carbapenems }\end{array}$ \\
\hline Nasir et al. a [29] & $\begin{array}{l}\text { Pakistan } \\
(2015-2017)\end{array}$ & Retrospective & $n=89$ & $n=174$ & E. coli $(100 \%)$ & $\begin{array}{l}\text { BSI }(100 \%) \\
\text {-UTI }(66 \%) \\
\text {-CIAI }(23 \%) \\
\text {-CRBSI }(3 \%) \\
\end{array}$ & $\begin{array}{c}\text { ICU: } 38 \% \\
\text { Septic shock: } 17 \%\end{array}$ & $\begin{array}{l}\text { In-hospital mortality: } 13 \% \\
\text { vs 21\% (ns) }\end{array}$ & $\begin{array}{l}\text { PTZ appeared to have } \\
\text { similar efficacy to } \\
\text { carbapenems }\end{array}$ \\
\hline Sharara et al. [30] & USA (2014-2016) & Retrospective & $n=45$ & $n=141$ & $\begin{array}{l}\text { E. coli }(56 \%) \\
\text { K. pneumoniae }(30 \%) \\
\text { P. mirabilis }(10 \%) \\
\text { K. oxytoca }(4 \%)\end{array}$ & UTI $(100 \%)$ & ICU: $26 \%$ & $\begin{array}{c}\text { 30-day mortality: } 4 \% \text { vs } \\
7 \% \text { (ns) }\end{array}$ & $\begin{array}{l}\text { PTZ appeared to have } \\
\text { similar efficacy to } \\
\text { carbapenems. Patients } \\
\text { treated with carbapenem } \\
\text { had higher incident of } \\
\text { carbapenem-resistant } \\
\text { organism isolated in } 60 \mathrm{~d} \\
(p=0.09)\end{array}$ \\
\hline
\end{tabular}


In a multicenter retrospective cohort study conducted in Singapore, empiric PTZ (94 patients) vs. carbapenems (57 patients) was compared in patients with either ESBL E. coli (=101) or ESBLK. pneumoniae (=50) BSI [21]. Thirty-day mortality did not differ between the two groups (30.9\% vs. 29.8\%, $p=0.89)$, whereas PTZ was connected with fewer multidrug-resistant organisms (MDRO) and fungal superinfections compared to carbapenems $(7.4 \%$ vs. $24.6 \%, p<0.01)$. The authors pointed out that for a PTZ MIC of $\leq 16 \mathrm{mg} / \mathrm{L}, \mathrm{PTZ}$ is reasonable to be administered at a dose of $3.375 \mathrm{~g} / 8 \mathrm{~h}$ with $4 \mathrm{~h}$ infusion. Therefore, the mode of administration is important to evaluate when considering the efficacy of PTZ in the comparable arms of therapy [21].

In a prospective randomized open-label comparison trial with a limited number of 64 patients with febrile healthcare-associated complicated urinary tract infections (cUTIs) with ESBL-producing E. coli, the efficacy of PTZ was compared to ertapenem [23]. Regarding clinical and microbiological success of PTZ versus ertapenem, the former reached $93.9 \%$ vs. $97.0 \%$ and $97.0 \%$ vs. $97.0 \%$ respectively, with a 28 -day mortality of $6.1 \%$ equal in the two groups. The authors concluded that "PTZ is effective in the treatment of UTIs caused by ESBL-producing E. coli whenever the MIC is $\leq 1 \mathrm{mg} / \mathrm{L}^{\prime \prime}$.

Similarly, a retrospective observational targeted study of PTZ (68 patients) vs. ertapenem (82 patients) for acute pyelonephritis caused by ESBL-PE (possessing MIC to PTZ of $\leq 8 \mu \mathrm{g} / \mathrm{mL}$ ) was performed [24]. No significant difference between PTZ and ertapenem regarding the primary end-points of the study, that is, microbiological eradication failure (4.4\% vs. $4.9 \%$ ), in-hospital mortality $(4.4 \%$ vs. $13.4 \%)$ and change of initial antibiotic regimen $(14.7 \%$ vs. $22.0 \%)$, were observed. In the multivariate analysis, predictors of treatment failure included septic shock and recent administration of immunosuppressive agents; however, the type of the administered antibiotic was not associated with treatment outcome.

The results of two metanalyses referring to carbapenems versus alternative antibiotics for treating ESBL-PE BSI, both published in 2018, are quite interesting [32,33]. In the first metanalysis, 35 publications (until 2016) fulfilled the inclusion criteria [32]. Whenever antibiotics were given empirically, no significant differences related to overall mortality were observed between carbapenems and non-carbapenems. As it concerns definitive therapy, overall mortality was lower for patients given carbapenems compared to cephalosporins and non-BLBLIs, whereas no differences between carbapenems and BLBLIs, as well as quinolones and aminoglycosides, were observed. Despite the absence of differences when BLBLIs were compared to carbapenems, the authors pointed out the lack of robust data derived from randomized controlled trials, as well as the heterogeneity of the study population.

In the second metanalysis, 25 observational studies (until 2017) including 3847 patients were analyzed [33]. Thirty-day mortality of BLBLIs or PTZ was not statistically different from carbapenems either as empirical or definitive therapy. Moreover, the authors suggested that PTZ may be considered as an alternative treatment for ESBL-PE BSI, particularly when the MIC is low $(\leq 4 \mathrm{mg} / \mathrm{L})$ and/or the source of the infection is abdominal or genito-urinary. Sfeir et al. [33] also pointed out the limitations encountered in their review, such as the observational character and the heterogeneity of the studied population, as well as the lack of information on the mode of administration of PTZ (i.e., high dose and continuous 4 $\mathrm{h}$ infusion for achieving adequate PK/PDs therapeutic targets [10]). However, the reported limitations should not be an obstacle for suggesting PTZ at high dose and continuous infusion as a non-inferior carbapenem-sparing agent against ESBL-PE. It is of great importance to mention that PTZ is not suitable for deep-seated infections associated with high inoculum (where carbapenems should be preferred), since PTZ possesses a strong inoculum effect leading to $\geq 8$-fold increase in the MIC [34].

The results regarding the efficacy of PTZ in infections caused by ESBL-PE are based mainly on retrospective studies and are controversial (Table 1). The so-called MERINO trial [26,35] was conducted to answer the key question "Can PTZ be used as carbapenem sparing therapy in patients with bloodstream infections caused by ceftriaxone-resistant E. coli or K. pneumoniae that test susceptible to PTZ and meropenem?". The MERINO study was an international, multicenter, noninferiority, open-label, parallel group, randomized clinical trial comparing 30-day mortality of PTZ (4.5 g q6h) vs. meropenem ( $1 \mathrm{~h} \mathrm{q} 8 \mathrm{~h})$ both infused over $30 \mathrm{~min}$, as definitive therapy in adult patients with ceftriaxone-resistant E. coli or K. pneumoniae BSI. Randomization was performed within $72 \mathrm{~h}$ of blood 
culture collection, and patients received study drugs for a minimum of $4 \mathrm{~d}$ and a maximum of $14 \mathrm{~d}$ after randomization with an arbitrary length of treatment arranged by the treating physician. A 5\% noninferiority margin was used. Patients were screened for enrollment in 26 hospitals in 9 countries (Australia, New Zealand, Singapore, Italy, Turkey, Lebanon, South Africa, South Arabia and Canada) starting February 2014 until July 2017. Stratification included infecting species, presumed source of infection (UTI or elsewhere) and infection severity (Pitt bacteremia score $\leq 4$ or $>4$ ). Primary outcome was all-cause mortality at $30 \mathrm{~d}$ post randomization, with secondary outcomes including (a) time to clinical and microbiological resolution of infection; (b) clinical and microbiological success at day 4 post randomization; (c) microbiologic resolution of infection; (d) bloodstream infection relapse; (e) superinfection with meropenem or PTZ-resistant microorganisms or Clostridium difficile infections. Finally, out of 1646 screened patients, 378 were randomized (191 in meropenem and 188 in PTZ group). Although balanced with respect to baseline characteristics, more patients in the meropenem group had diabetes, a urinary source of bacteremia and higher APACHE II scores (41.4\% vs. 31.4\%, $67.0 \%$ vs. $54.8 \%$ and $21.0 \%$ vs. $17.9 \%$ respectively), whereas in the PTZ group more patients were immunocompromised ( $27.1 \%$ vs. $20.9 \%$ accordingly). A total of 23 patients (12.3\%) receiving PTZ vs. $7(3.7 \%)$ in the meropenem group met the primary outcome of 30-day mortality ( $p=0.90$ for noninferiority). In microbiological analysis, a total of 306 isolates were available (266 E. coli and $40 \mathrm{~K}$. pneumoniae) with median MIC to PTZ of $2 \mathrm{mg} / \mathrm{L}$ (IQR 1.5-4 mg/L) and median MIC to meropenem of $0.023 \mathrm{mg} / \mathrm{L}$ (IQR $0.016-0.032 \mathrm{mg} / \mathrm{L}$ ). ESBL genes were confirmed in $85.3 \%$ isolates with $10.2 \%$ possessing acquired AmpC genes and $2 \%$ both. Narrow-spectrum oxacillinases $\left(b l a_{\mathrm{OXA}-1}\right)$, which may compromise $\beta$-lactamase inhibition by tazobactam, were identified in $67.6 \%$ of the strains. The authors stated that "PTZ should no longer be considered an alternative to meropenem for definitive treatment of bloodstream infections due to ceftriaxone-resistant E. coli and K. pneumoniae" [26]. However, certain limitations should be taken into consideration: (a) the inherent delay in blood cultures processing and susceptibility results, indicating that empiric therapy was not throughout under control; (b) the fact that "step down therapy" occurred only in $20.1 \%$ of carbapenem-treated patients; (c) crossover of patients from one group to the other was allowed; (d) the lack of information regarding adequate source control; (e) the presence of acquired AmpC in 10.2\% of the strains could have an impact on PTZ efficacy, since such enzymes reduce $\beta$-lactamase inhibition by tazobactam at least in vitro [9]; (f) due to unblind study design, investigators were aware of the treatment allocation, prompting therefore early cessation of PTZ; $(\mathrm{g})$ the acuity of infection was lower than expected; $(\mathrm{h})$ the high percentage of patients $(40.7 \%)$ with resolved signs of infection at the randomization day, providing strong evidence against the noninferiority of PTZ [26,35].

Finally, certain questions were left unanswered in the MERINO trial [26]. Questions that need to be answered, however, are whether PTZ given in extended or constant infusion is efficacious, as well as the effectiveness of PTZ in cases of empirical therapy of bacteremia or in the treatment of non-bacteremic ESBL-PE infections. Probably, a European plus a USA blinded trial (similar to MERINO), taking into account the reported limitations analyzed, could give answers to the existing questions. In the meantime, it seems preferable, whenever a carbapenem-sparing decision is pending, to seriously consider the Tamma and Rodríguez-Baño et al. [18] positions.

\section{Ceftolozane-Tazobactam}

Ceftolozane-tazobactam is a novel combination of a cephalosporin with a $\beta$-lactamase inhibitor that exhibits excellent in vitro activity against a broad spectrum of Enterobacterales and Pseudomonas aeruginosa, including ESBL strains, and has been recently approved for the treatment of complicated intra-abdominal infections (cIAI) and cUTI [36]. The in vitro activity of ceftolozane-tazobactam against ESBL-PE from U.S. hospitals revealed an overall susceptibility of $83.9 \%$ (CLSI/EUCAST breakpoints) to ceftolozane-tazobactam. Ceftolozane-tazobactam inhibited $95.5 \%$ of the E. coli isolates, but only $83 \%$ of K. pneumoniae producing ESBL. Regarding ESBL-encoding genes, ceftolozane-tazobactam inhibited $92.9 \%$ of the isolates harboring bla ${ }_{\mathrm{CTX}-\mathrm{M}}$ and exhibited limited activity against isolates carrying bla $\mathrm{SHV}_{\mathrm{S}}$ 
(61.1\% susceptible) [37]. In phase III randomized clinical trials, ceftolozane-tazobactam (in combination with metronidazole) demonstrated similar efficacy to meropenem for the treatment of cIAIs [38] and superior efficacy to levofloxacin for the treatment of cUTIs, including pyelonephritis [39]. Also, in a phase 3 trial with nosocomial infections, ceftolozane-tazobactam was compared to meropenem and in patients with ESBL-PE, and clinical cure rates were 57.1\% (48/84) and 61.6\% (45/73) respectively [40]. In a pooled analysis of phase III clinical trials, a total of 159 ESBL-PE isolates from the microbiologically evaluable population, mostly E. coli (68.6\%), were identified. Overall, $72.3 \%$ of ESBL isolates were susceptible to ceftolozane-tazobactam versus $98.3 \%$ to meropenem, whereas only $24.1 \%$ were susceptible to levofloxacin at EUCAST breakpoints. Clinical cure rates against ESBL isolates in cUTIs treated with ceftolozane-tazobactam and levofloxacin were $95.8 \%$ and $82.6 \%$ respectively, whereas in cIAIs, clinical cure rates depicted were $98.1 \%$ for the ceftolozane-tazobactam group and $88.5 \%$ for the meropenem group [41]. It is of great significance to point out that, in a cost effectiveness analysis comparing carbapenem-sparing agents versus meropenem, patients with cUTIs due to ESBL receiving ceftolozane-tazobactam were found cost-effective compared to meropenem [42]. Although the limited data available for ESBL pathogens are extrapolated from clinical trials to preclude robust analysis, ceftolozane-tazobactam seems as an attractive option for a carbapenem-sparing strategy depending on local antibiotic stewardship decisions. However, more evidence is needed to confirm the exact place of ceftolozane-tazobactam for ESBL infections.

\section{Ceftazidime-Avibactam}

Avibactam, a novel non-b-lactam, b-lactamase inhibitor, restores the activity of ceftazidime against the majority of $\beta$-lactamases (ESBLs and carbapenemases, including Klebsiella pneumoniae carbapenemase (KPCs) and OXA-48), resulting in activity of ceftazidime-avibactam combination against a wide range of MDR Gram-negative bacteria [43,44]. In vitro activity of ceftazidime-avibactam against Enterobacterales from 18 European countries as part of the International Network for Optimal Resistance Monitoring (INFORM) global surveillance program from 2012 to 2015 revealed ceftazidime-avibactam was the most active agent, compared with all other tested comparator agents, against non-susceptible ceftazidime isolates (97.7\% susceptible) [45]. A post hoc analysis of phase 2 trials summarizing the results of ESBL-PE isolates recovered at baseline revealed a favorable outcome in the ceftazidime-avibactam and meropenem arms in $85.7 \%$ and $80.0 \%$ of patients, respectively [46]. Similarly, clinical cure rates from patients enrolled in phase 3 clinical trial regarding cUTIs revealed efficacies of $90.3 \%$ and $89.1 \%$ for the ceftazidime-avibactam and doripenem groups accordingly [47], highlighting a potential role for ESBL infections. However, it should be taken into consideration that ceftazidime-avibactam is one of the limited options for carbapenemase-producing Enterobacterales [44]. Therefore, it should be preserved for the treatment of KPC and OXA-48 producers and should not be recommended as a carbapenem-sparing strategy.

\section{Cephamycins}

Cephamycins include cefoxitin, cefotetan, cefmetazole, moxalactam and flomoxef. They belong to a subclass of second-generation cephalosporins that confers resistance to degradation by ESBL enzymes. However, cephamycins are not active against AmpC cephalosporinases and porin mutations [48]. Eight observational studies comparing the efficacy of cephamycins and carbapenems in infections (mainly UTIs and bacteremia) due to ESBL-PE have been published to date and are illustrated in Table 2 [49-56]. In the majority of the studies, no difference regarding mortality was observed $[49,51-53,55,56]$ with the exception of two studies $[50,54]$. The major drawbacks of the studies were the small population size, inadequate control for confounders and low statistical power, whereas carbapenems were administrated in more severe infections and mostly in bacteremic patients [49-56]. Lee et al. [54] found similar mortality rates with flomoxef and carbapenems when the MIC of flomoxef was $\leq 1 \mathrm{mg} / \mathrm{L}$, but when MIC was $4-8 \mathrm{mg} / \mathrm{L}$, cefoxitin was found inferior to carbapenem. Also, cefoxitin has been studied in UTIs in males. Twenty-three patients were included in the cefoxitin group and 27 in the carbapenem group. No significant difference was illustrated for clinical and microbiological success between the two groups in univariate and multivariable models. An interesting point was that cefoxitin administrated at high dose and continuous infusion was associated with clinical success [56]. 
Table 2. Clinical studies comparing the efficacy of cephamycins versus carbapenems in infections caused by ESBL-producing Enterobacterales [49-56].

\begin{tabular}{|c|c|c|c|c|c|c|c|c|c|}
\hline Study & $\begin{array}{l}\text { Country of } \\
\text { Study (Period } \\
\text { of Study) }\end{array}$ & Study Design & $\begin{array}{l}\text { Cephamycin }(n, \\
\text { Number of } \\
\text { Participants) } \\
\end{array}$ & $\begin{array}{l}\text { Carbapenems }(n, \\
\text { Number of } \\
\text { Participants) }\end{array}$ & Organism(s) & Site of Infection & $\begin{array}{l}\text { Severity of Illness } \\
\text { at Infection Onset }\end{array}$ & $\begin{array}{l}\text { Outcome (Cephamycins vs } \\
\text { Carbapenems) }\end{array}$ & Comments \\
\hline Lee et al. [49] & $\begin{array}{l}\text { Taiwan } \\
(2004-2005)\end{array}$ & Retrospective & $n=7$ (flomoxef) & $n=20$ & К. риеитопіае (100\%) & BSI $(100 \%)$ & ICU: $52 \%$ & 14-day mortality: $29 \%$ vs $25 \%$ (ns) & $\begin{array}{l}\text { No difference between } \\
\text { cephamycin and carbapenem } \\
\text { treatment. Patients in the } \\
\text { carbapenem group were more } \\
\text { severely ill }\end{array}$ \\
\hline Yang et al. [50] & $\begin{array}{c}\text { Taiwan } \\
(2001-2007)\end{array}$ & Retrospective & $n=29$ (flomoxef) & $n=28$ & K. pneumoniae $(100 \%)$ & BSI (100\%) & ICU: $51 \%$ & $\begin{array}{l}\text { 14-day mortality: } 55 \% \text { vs } 39 \% \text { ( }<< \\
0.05)\end{array}$ & $\begin{array}{l}\text { Hemodialysis } \\
\text { access-related bacteremia } \\
\text { included in the study. } \\
\text { Cephamycin use was } \\
\text { independently associated with } \\
\text { increased mortality (OR, 3.52; } \\
\text { 95\% CI, 1.19-58.17) }\end{array}$ \\
\hline Doi et al. [51] & $\begin{array}{c}\text { Japan } \\
(2008-2010)\end{array}$ & Retrospective & $n=10$ (cefmetazole) & $n=12$ & $\begin{array}{l}\text { E. coli }(95 \%) \\
\text { K. pneumoniae (5\%) }\end{array}$ & UTI (100\%) & NR & $\begin{array}{l}\text { Clinical cure (4-weeks): } 90 \% \text { vs } \\
100 \% \text { (ns) }\end{array}$ & $\begin{array}{l}\text { No difference in clinical or } \\
\text { bacteriological cure rate at } 4 \mathrm{w}\end{array}$ \\
\hline Pilmis et al. [52] & France (2011) & Retrospective & $n=8$ (cefoxitin) & $n=31$ & $\begin{array}{l}\text { E. coli }(32 \%) \\
\text { K. pneumoniae }(32 \%) \\
\text { E. cloacae }(36 \%)\end{array}$ & $\begin{array}{l}\text { UTI }(75 \%) \\
\text { BSI }(25 \%)\end{array}$ & NR & $\begin{array}{l}\text { Clinical and microbiological } \\
\text { relapse (30-days): } 13 \% \text { vs } 23 \% \text { (ns) }\end{array}$ & $\begin{array}{l}\text { No difference between } \\
\text { cephamycin and carbapenem } \\
\text { treatment }\end{array}$ \\
\hline $\begin{array}{l}\text { Matsumura et al. } \\
{[53]}\end{array}$ & $\begin{array}{c}\text { Japan } \\
(2005-2014)\end{array}$ & Retrospective & $\begin{array}{l}\text { Empiric, } n=8 \\
\text { Definitive, } n=59 \\
\text { (cefmetazole or } \\
\text { flomoxef) }\end{array}$ & $\begin{array}{c}\text { Empiric, } n=45 \\
\text { Definitive, } n=54\end{array}$ & E. coli $(100 \%)$ & BSI $(100 \%)$ & Septic shock: $41 \%$ & $\begin{array}{l}\text { 30-day mortality (empiric arm): 8\% } \\
\text { vs 9\% (ns) } \\
\text { 30-day mortality (definitive arm): } \\
\text { 5\% vs 9\% (ns) }\end{array}$ & $\begin{array}{l}\text { No difference between } \\
\text { cephamycin and carbapenem } \\
\text { treatment }\end{array}$ \\
\hline Lee et al. [54] & $\begin{array}{l}\text { Taiwan } \\
(2007-2012)\end{array}$ & Retrospective & $n=123$ (flomoxef) & $n=257$ & $\begin{array}{l}\text { K. pneumoniae }(60 \%) \\
\text { E. coli }(40 \%)\end{array}$ & BSI $(100 \%)$ & $\begin{array}{l}\text { Pitt bacteremia } \\
\text { score } \\
\quad \geq 4: 66 \%\end{array}$ & 30-day mortality: $28.8 \%$ vs $12.8 \%$ & $\begin{array}{l}\text { Definitive flomoxef therapy } \\
\text { appears to be inferior to } \\
\text { carbapenems, particularly for } \\
\text { isolates with a MIC flomoxef of } \\
2-8 \mathrm{mg} / \mathrm{L}\end{array}$ \\
\hline Fukuchi et al. [55] & $\begin{array}{c}\text { Japan } \\
(2008-2013)\end{array}$ & Retrospective & $n=26$ (cefmetazole) & $n=43$ & $\begin{array}{l}\text { E. coli }(94 \%) \\
\text { K. pneumoniae }(3 \%) \\
\text { K. oxytoca }(3 \%)\end{array}$ & BSI $(100 \%)$ & ICU: $32 \%$ & 30-day mortality: $4 \%$ vs $16 \%$ (ns) & $\begin{array}{l}\text { No difference between } \\
\text { cephamycin and carbapenem } \\
\text { treatment. The group that } \\
\text { received carbapenem therapy } \\
\text { had increased severity }\end{array}$ \\
\hline Senard et al. [56] & $\begin{array}{c}\text { France } \\
(2013-2015)\end{array}$ & Retrospective & $n=23$ (cefoxitin) & $n=27$ & E. coli $(100 \%)$ & UTI (100\%) & Septic shock: $4 \%$ & $\begin{array}{l}\text { Clinical success: } 73.9 \% \text { vs } 81.5 \% \\
\text { (ns) } \\
\text { Clinical success: } 57.9 \% \text { vs } 50 \% \text { (ns) }\end{array}$ & $\begin{array}{l}\text { No difference between } \\
\text { cephamycin and carbapenem } \\
\text { treatment. In the cephamycin } \\
\text { group, continuous infusion was } \\
\text { associated with clinical success }\end{array}$ \\
\hline
\end{tabular}

BSI, blood stream infection; CI, confidence interval; ICU, intensive care unit; NR, not reported; ns, not significant; OR, odds ratio; UTI, urinary tract infection; vs, versus. 
The available data suggest that cephamycins may be an alternative to carbapenems for some non-severe infections, particularly UTIs, and should be administrated at high dose and continuous infusion.

\section{Cefepime}

Cefepime, a "fourth-generation" cephalosporin, possesses in vitro activity against most Gram-negative pathogens, including Enterobacterales, due in part to its relatively low susceptibility to degradation by chromosomal and plasmid-mediated extended-spectrum AmpC lactamases and ESBLs compared to that of other cephalosporins [57]. CLSI breakpoints for cefepime MIC against the Enterobacterales family are $2 \mathrm{mg} / \mathrm{L}$ (susceptible), 4-8 mg/L (susceptible dose dependent; SDD) and 16 $\mathrm{mg} / \mathrm{L}$ (resistant) [58]. In contrast, EUCAST breakpoints for cefepime MIC are $1 \mathrm{mg} / \mathrm{L}$ (susceptible) and $4 \mathrm{mg} / \mathrm{L}$ (resistant) [59]. However, MICs of cefepime for Gram-negative organisms that produce ESBLs are often increased compared to non-producers [57]. A retrospective study by Bhat et al. [60] provided an important opportunity to advance our knowledge regarding the rate of mortality in correlation to cefepime MIC. The rates of mortality were $23.3 \%$ and $27.8 \%$ for infections with a cefepime MIC of $<1$ $\mathrm{mg} / \mathrm{L}$ and $2 \mathrm{mg} / \mathrm{L}$ respectively, mounting to $53.3 \%$ and $56.3 \%$ with a MIC of 8 and $16 \mathrm{~g} / \mathrm{mL}$ accordingly, highlighting the use of cefepime for non-severe infections only with MIC $\leq 2 \mathrm{mg} / \mathrm{L}$ [60].

On the other hand, concerns of diminished efficacy of cefepime for the treatment of ESBL infections with high bacterial inoculum (i.e., pneumonia, osteoarthritis and endocarditis, so called "inoculum effect" in which there is a marked increase in MIC with increased inoculum), has been illustrated in animal studies $[34,61,62]$. In order to highlight this phenomenon, inkjet printing technology testing the inoculum effect on cefepime was performed in a recent study with ESBL Escherichia coli and Klebsiella spp. In 13 cefepime-resistant and SDD strains, as well as 11 cefepime-susceptible isolates, a 2-fold increase in inoculum resulted in a $1.6 \log _{2}$-fold increase in MIC. In contrast, in cefepime-susceptible, non-ESBL producing clinical strains, only a minor inoculum effect at very high inocula $\left(>10^{7} \mathrm{cfu} / \mathrm{mL}^{-1}\right)$ was depicted [63].

Although some observational data have suggested that high-dose cefepime (e.g., 2 g every eight hours) can be effective for the treatment of ESBL-producing infections as a carbapenem-sparing agent $[64,65]$, superiority of carbapenem treatment has been highlighted regarding therapy of ESBL infections [66-69]. The clinical studies comparing the efficacy of cefepime versus carbapenems in infections caused by ESBL-PE are illustrated in Table 3 [23,27,64-71]. Chopra et al. [66] outlined in a multivariate analysis that empirical therapy with cefepime for BSI due to an ESBL-producing pathogen was associated with a trend toward an increased mortality risk, and empirical carbapenem therapy was associated with a trend toward decreased mortality risk. Likewise, in a retrospective study of 178 patients with monomicrobial bacteremia caused by ESBL producers, cefepime was administrated in 17 cases compared with 161 patients treated with a carbapenem. Multivariable analysis manifested that cefepime therapy was independently associated with a poor outcome. Moreover, increased risk of clinical and microbiological failure as well as sepsis-related mortality was illustrated with cefepime therapy. However, an interesting finding was the favorable outcome in patients treated with cefepime with bacteremia caused by ESBL-producing organisms only when cefepime MIC was $\leq 1 \mathrm{mg} / \mathrm{L}$ [67]. Similarly, in a randomized trial of patients with UTIs caused by ESBL-PE, treatment failure with cefepime was higher compared with ertapenem or piperacillin-tazobactam [23]. Wang et al. [68] conducted a propensity score-match study of 17 patients receiving empiric cefepime therapy versus 51 patients receiving carbapenem therapy for ESBL bacteremia. Patients receiving carbapenem were 2.87 times more likely to survive than patients receiving cefepime. The dilemma of carbapenem-sparing strategies in bacteremic patients caused by ESBL-producing E. coli with hematologic malignancies has been evaluated in a retrospective study comparing carbapenems (42 pts) vs. cefepime (40 pts). In multivariate analysis, empiric treatment with cefepime was not associated with increased 14-day or 30-day mortality. However, time to defervescence $(p<0.01)$ and persistent bacteremia $(p=0.07)$ were associated with cefepime treatment, hindering the use of cefepime in this specific population [27]. 
Table 3. Clinical studies comparing the efficacy of cefepime versus carbapenems in infections caused by ESBL-producing Enterobacterales [23,27,64-71].

\begin{tabular}{|c|c|c|c|c|c|c|c|c|c|}
\hline Study & $\begin{array}{l}\text { Country of } \\
\text { Study (Period } \\
\text { of Study) }\end{array}$ & Study design & $\begin{array}{l}\text { Cefepime ( } n, \\
\text { Number of } \\
\text { Participants) } \\
\text { (Dosage) }\end{array}$ & $\begin{array}{c}\text { Carbapenems ( } n, \\
\text { Number of } \\
\text { Participants) } \\
\text { (Dosage) } \\
\end{array}$ & Organism(s) & Site of Infection & $\begin{array}{l}\text { Severity of Illness } \\
\text { at Infection Onset }\end{array}$ & $\begin{array}{l}\text { Outcome (Cefepime vs } \\
\text { Carbapenems) }\end{array}$ & Comments \\
\hline Zanetti et al. [64] & $\begin{array}{c}\text { Six European } \\
\text { countries } \\
(1997-1999)\end{array}$ & $\begin{array}{l}\text { Randomized } \\
\text { trial }\end{array}$ & $n=13(2 \mathrm{gr}$ q $8 \mathrm{~h})$ & $\begin{array}{l}n=10(\text { IMP } 500 \\
\text { mg q qh) }\end{array}$ & $\begin{array}{l}\text { K. pneumoniae }(96 \%) \\
\text { E. aerogenes }(4 \%)\end{array}$ & $\begin{array}{l}\text { Pneumonia } \\
(100 \%)\end{array}$ & ICU $(100 \%)$ & $\begin{array}{l}\text { Clinical response: } 69 \% \text { vs } 100 \% \text { ( } p \\
<0.05)\end{array}$ & $\begin{array}{l}\text { Comparison for ESBL producers } \\
\text { not included }\end{array}$ \\
\hline Goethaert et al. [65] & $\begin{array}{l}\text { Belgium } \\
(1994-2000)\end{array}$ & Retrospective & $n=21(2 \mathrm{gr}$ q $8 \mathrm{~h})$ & $\begin{array}{l}n=23 \text { (IMP } 500 \\
\text { mg q6h, MEM 1 } \\
\text { gr q8h) }\end{array}$ & E. aerogenes (TEM-24) & $\begin{array}{l}\text { Pneumonia }(64 \%) \\
\text { BSI }(16 \%) \\
\text { cIAI }(14 \%) \\
\text { UTI }(5 \%) \\
\text { Other }(0.3 \%) \\
\end{array}$ & ICU (100\%) & $\begin{array}{l}\text { Clinical response: } 62 \% \text { vs } 70 \% \\
\text { 30-day mortality: } 33 \% \text { vs } 26 \% \text { (ns) }\end{array}$ & $\begin{array}{l}\text { No statistically significant } \\
\text { differences } \\
\text { in the outcome for the cefepime } \\
\text { and carbapenem-treated groups }\end{array}$ \\
\hline Chopra et al. [66] & $\begin{array}{c}\text { USA } \\
(2005-2007)\end{array}$ & Retrospective & $\begin{array}{l}\text { Empiric: } \\
\text { monotherapy } n=43 \\
\text { Definitive: } \\
\text { monotherapy } n=9 \\
\text { (NR) }\end{array}$ & $\begin{array}{l}\text { Empiric: } \\
\text { monotherapy } \\
n=14 \\
\text { Definitive: } \\
\text { monotherapy } \\
n=33 \text { (NR) }\end{array}$ & $\begin{array}{l}\text { K. pneumoniae }(83 \%) \\
\text { E. coli }(17 \%)\end{array}$ & $\begin{array}{l}\text { BSI }(100 \%) \\
\text {-CRBSI (75\%) }\end{array}$ & ICU $(41 \%)$ & $\begin{array}{l}\text { In-hospital mortality } \\
\text { Empiric: } 40 \% \text { vs } 36 \% \text { (ns) } \\
\text { Definitive: } 33 \% \text { vs } 36 \% \text { (ns) }\end{array}$ & $\begin{array}{l}\text { Trend toward increased } \\
\text { mortality risk with empiric } \\
\text { cefepime therapy }\end{array}$ \\
\hline Lee et al. [67] & $\begin{array}{l}\text { Taiwan } \\
(2002-2007)\end{array}$ & Retrospective & $\begin{array}{l}\text { Empiric: } n=21 \\
\text { Definitive: } n=17 \\
\text { (1-2 g q8h) }\end{array}$ & $\begin{array}{l}\text { Empiric: } n=91 \\
\text { Definitive: } n=161 \\
\text { (IMP } 500 \text { mg q6h, } \\
\text { MEM } 1 \text { gr q8h, } \\
\text { ETP } 1 \text { g q24h) }\end{array}$ & $\begin{array}{c}\text { E. cloacae }(55 \%) \\
\text { E. coli }(24 \%) \\
\text { K. pneumoniae }(21 \%)\end{array}$ & $\begin{array}{l}\text { BSI }(100 \%) \\
\text {-Primary }(14 \%) \\
\text {-CRBSI }(21 \%) \\
\text {-Pneumonia }(24 \%) \\
\text {-UTI }(22 \%) \\
\text {-cIAI }(16 \%) \\
\text {-SSTI }(6 \%)\end{array}$ & $\begin{array}{l}\text { McCabe (Rapidly } \\
\quad \text { fatal): } 11 \% \\
\text { Pitt score } \geq 4: 67 \%\end{array}$ & $\begin{array}{l}\text { 30-day mortality: Definitive } \\
\text { therapy: } 59 \% \text { vs } 17 \%(p=0.01) \\
\text { Crude mortality: } 65 \% \text { vs } 37 \% \\
(p=0.04)\end{array}$ & $\begin{array}{l}\text { Cefepime definitive therapy } \\
\text { inferior to carbapenem therapy, } \\
\text { 30-day mortality was lower } \\
\text { when cefepime MIC } \leq 1 \mathrm{mg} / \mathrm{L}\end{array}$ \\
\hline Wang et al. [68] & $\begin{array}{c}\text { USA } \\
(2006-2015)\end{array}$ & Retrospective & $n=17(1-2 \mathrm{~g} \mathrm{q} 8 \mathrm{~h})$ & $\begin{array}{l}n=51 \\
\text { (IMP } 500 \mathrm{mg} \text { q6h, } \\
\text { MEM } 1 \text { gr q8h, } \\
\text { ETP } 1 \text { g q24h) }\end{array}$ & $\begin{array}{c}\text { Klebsiella spp. (63\%) } \\
\text { E. coli }(32 \%) \\
\text { P. mirabilis }(3 \%)\end{array}$ & $\begin{array}{l}\text { BSI }(100 \%) \\
\text {-CRBSI }(44 \%) \\
\text {-UTI }(31 \%) \\
\text {-Biliary }(9 \%) \\
\text {-Pneumonia }(15 \%) \\
\text {-cIAI }(13 \%) \\
\text {-SSTI: }(3 \%)\end{array}$ & ICU $(29 \%)$ & $\begin{array}{l}\text { 14-day mortality: } 41 \% \text { vs } 20 \% \\
(p=0.08)\end{array}$ & $\begin{array}{l}\text { Risk of death was } 2.87 \text { times } \\
\text { higher for patients receiving } \\
\text { cefepime compared with } \\
\text { carbapenems }\end{array}$ \\
\hline
\end{tabular}


Table 3. Cont.

\begin{tabular}{|c|c|c|c|c|c|c|c|c|c|}
\hline Study & $\begin{array}{l}\text { Country of } \\
\text { Study (Period } \\
\text { of Study) }\end{array}$ & Study design & $\begin{array}{l}\text { Cefepime ( } n, \\
\text { Number of } \\
\text { Participants) } \\
\text { (Dosage) }\end{array}$ & $\begin{array}{l}\text { Carbapenems ( } n \\
\text { Number of } \\
\text { Participants) } \\
\text { (Dosage) }\end{array}$ & Organism(s) & Site of Infection & $\begin{array}{l}\text { Severity of Illness } \\
\text { at Infection Onset }\end{array}$ & $\begin{array}{l}\text { Outcome (Cefepime vs } \\
\text { Carbapenems) }\end{array}$ & Comments \\
\hline Lee et al. [69] & $\begin{array}{l}\text { Taiwan } \\
(2008-2012)\end{array}$ & Retrospective & $\begin{array}{l}\text { Definitive: } n=42 \\
(1-2 \mathrm{~g} \text { q12h or q8h) }\end{array}$ & $\begin{array}{l}\text { Definitive: } n=53 \\
\text { (IMP } 500 \mathrm{mg} \text { q6h, } \\
\text { MEM } 1 \text { gr q8h, } \\
\text { ETP } 1 \mathrm{~g} \text { q24h) }\end{array}$ & E. cloacae $(100 \%)$ & $\begin{array}{l}\text { BSI }(100 \%) \\
\text {-CRBSI }(37 \%) \\
\text {-Primary }(31 \%) \\
\text {-Pneumonia }(9 \%) \\
\text {-UTI }(8 \%) \\
\text {-CIAI: }(8 \%) \\
\text {-SSTI: }(6 \%)\end{array}$ & $\begin{array}{l}\text { McCabe (Rapidly } \\
\quad \text { fatal): } 15 \% \\
\text { Pitt score } \geq 4: 39 \%\end{array}$ & $\begin{array}{l}\text { 30-day mortality: } 26.4 \% \text { vs } 22.2 \% \\
\text { (ns) } \\
\text { 30-day mortality } \\
\text { (bacteremia due to ESBL): } \\
100 \% \text { vs } 42.9 \%(\mathrm{p}=0.015)\end{array}$ & $\begin{array}{l}\text { Comparison for definitive } \\
\text { therapy due to ESBL bacteremia } \\
\text { with cefepime SDD isolates only } \\
\text { reported }\end{array}$ \\
\hline Benanti et al. [27] & $\begin{array}{c}\text { USA } \\
(2008-2015)\end{array}$ & Retrospective & $n=40(2 \mathrm{~g} \mathrm{q} 8 \mathrm{~h})$ & $\begin{array}{l}n=42(\text { MEM } 1 \mathrm{~g} \\
\text { q8h) }\end{array}$ & E. coli $(100 \%)$ & $\begin{array}{l}\text { BSI (100\%) } \\
\text {-CRBSI }(19 \%) \\
\text {-Primary }(16 \%) \\
\text {-Pneumonia }(9 \%) \\
\text {-UTI }(7 \%) \\
\text {-CIAI }(43 \%) \\
\text {-SSTI }(6 \%)\end{array}$ & $\begin{array}{c}\text { ICU: } 26 \% \\
\text { Leukemia: } 79 \% \\
\text { Prior HCT: } 50 \%\end{array}$ & 14-day mortality: $8 \%$ vs $19 \%$ (ns) & $\begin{array}{l}\text { No difference between cefepime } \\
\text { and carbapenem therapy }\end{array}$ \\
\hline Seo et al. [23] & Korea & $\begin{array}{l}\text { Randomized } \\
\text { trial }\end{array}$ & $n=6(2 \mathrm{~g}$ q12h $)$ & $\begin{array}{l}n=33(\text { ETP } 1 \mathrm{~g} \\
\mathrm{q} 24 \mathrm{~h})\end{array}$ & E. coli $(100 \%)$ & UTI $(100 \%)$ & $\begin{array}{l}\text { Charlson index: } 5 \\
\text { Septic shock: } 33 \%\end{array}$ & $\begin{array}{l}\text { Clinical and microbiological } \\
\text { response: } 33.3 \% \text { vs } 97 \%(p<0.01)\end{array}$ & $\begin{array}{l}\text { Cefepime therapy inferior to } \\
\text { carbapenem therapy }\end{array}$ \\
\hline Suh et al. [70] & $\begin{array}{c}\text { Korea } \\
(2014-2016)\end{array}$ & Retrospective & $\begin{array}{l}n=54(2 \mathrm{~g} \mathrm{q} 8 \mathrm{~h} \text { or } \\
\mathrm{q} 12 \mathrm{~h})\end{array}$ & $\begin{array}{l}n=101(\text { ETP } 1 \mathrm{~g} \\
\text { q24h) }\end{array}$ & E. coli $(100 \%)$ & UTI (100\%) & $\begin{array}{l}\text { Charlson index: } 2 \\
\text { Septic shock: } 6.5 \%\end{array}$ & $\begin{array}{l}\text { In-hospital mortality: } 9.3 \% \text { vs } 9.9 \% \\
\text { (ns) }\end{array}$ & $\begin{array}{l}\text { No difference between cefepime } \\
\text { and carbapenem therapy }\end{array}$ \\
\hline Kim et al. [71] & $\begin{array}{c}\text { USA } \\
(2014-2017)\end{array}$ & Retrospective & $\begin{array}{l}n=17(1-2 \mathrm{~g} \mathrm{q} 12 \mathrm{~h} \\
\text { or } 2 \mathrm{~g} \text { q } 8 \mathrm{~h})\end{array}$ & $n=89(\mathrm{NR})$ & $\begin{array}{c}\text { E. coli }(82 \%) \\
\text { K. pneumoniae }(18 \%)\end{array}$ & UTI (100\%) & ICU: $13 \%$ & $\begin{array}{l}\text { Clinical and microbiological } \\
\text { response: } 100 \% \text { vs } 100 \% \text { (ns) } \\
\text { Relapse (30-day): } 0 \% \text { vs 7\% }\end{array}$ & $\begin{array}{l}\text { Comparable effectiveness } \\
\text { between cefepime and } \\
\text { carbapenems for UTIs }\end{array}$ \\
\hline
\end{tabular}

BSI, blood stream infection; cIAI, complicated intra-abdominal infection; CRBSI, catheter-related blood stream infection; ETP, ertapenem; ESBL, extended spectrum $\beta$-lactamase; HCT, hematopoietic stem cell transplant; ICU, intensive care unit; IMP, imipenem-cilastatin; MEM, meropenem; NR, not reported; ns, not significant; q24h, every 24 h; q12h, every 12 h; q8h, every 8 h; q6h, every 6 h; SDD, susceptible dose dependent; SSTI, skin and soft tissue infection; UTI, urinary tract infection; vs, versus. 
In conclusion, the existing literature suggests that cefepime may be suboptimal for invasive ESBL infections. The use of cefepime for serious infection is not safely recommended and has been related to high mortality risk. However, cefepime could be suggested for low-risk infections caused by ESBL (i.e., UTIs with the supposition of a MIC to cefepime $\leq 2 \mathrm{mg} / \mathrm{L}$ administrated at a high dose $2 \mathrm{~g}$ every $8 \mathrm{~h}$ as a prolonged infusion).

\section{Temocillin}

Temocillin is a b-a-methoxy-derivative of ticarcillin that is only available in UK, Belgium, France and Luxembourg [72]. The chemical modification of ticarcillin to temocillin increased its stability to $\beta$-lactamases. Temocillin possesses very attractive characteristics: narrow spectrum mainly restricted to Enterobacterales, high resistance to hydrolysis by numerous $\beta$-lactamases including ESBL and hyperproduced AmpC and minimal risk of Clostridium difficile infection [72]. Against a collection of 157 ESBL-producing E. coli and 95 ESBL-producing K. pneumoniae strains harvested in 2015 from three French centers, in vitro susceptibility to temocillin was observed in $71.3 \%$ of the ESBL-producing E. coli and in $77.9 \%$ of the ESBL-producing K. pneumoniae tested, according to the Antibiogram Committee of the French Society for Microbiology guidelines. These rates increased to $98.7 \%$ and $98.9 \%$ according to the urinary tract infection breakpoint (i.e., $32 \mathrm{mg} / \mathrm{L}$ ) of the British Society for Antimicrobial Chemotherapy [73]. Similarly, susceptibility rate was $94.6 \%$ according to the $8 \mathrm{mg} / \mathrm{L}$ clinical breakpoint against ESBL-producing isolates from community-acquired UTI [74]. The largest experience on the efficacy of temocillin refers to a retrospective study in 92 patients in whom the drug was given for UTIs, bacteremia and hospital-acquired pneumonia (HAP) caused by Enterobacterales-producing ESBL and/or derepressed AmpC b-lactamases. Clinical and bacteriological efficacies of $86 \%$ and $84 \%$ were reported. However, the significance of an optimal therapeutic regimen of $2 \mathrm{~g}$ every $12 \mathrm{~h}$ was pointed out since clinical efficacy and microbiological eradication dropped significantly when suboptimal doses were administrated [75]. On the other hand, a dosage of temocillin of $6 \mathrm{~g}$ daily given by continuous infusion in critically ill patients from a PK/PDs aspect managed to cover infections caused by Enterobacterales with an MIC up to $16 \mathrm{mg} / \mathrm{L}$ [76]. Taking into consideration cost analysis, temocillin was found cost effective in patients with cUTIs due to ESBL compared to carbapenems, even when a three-year Markov model was applied [42]. Moreover, the impact on intestinal colonization resistance regarding temocillin was marginal, whereas carbapenems, and specifically ertapenem, were found to be a stronger driver of intestinal dysbiosis and colonization resistance alteration [77]. Concluding, temocillin, with its rather unique characteristics may act as an alternative to carbapenems for the treatment of ESBL Enterobacterales infections such as systemic UTIs. However, large-scale randomized trials are needed to shed light on the true efficacy of temocillin for the treatment of serious infections caused by ESBL-PE.

\section{Quinolones}

Plasmid-mediated quinolones resistance (PMQR) determinants frequently appear associated with extended-spectrum ESBL genes [78]. A study from Canada including outpatients revealed quinolone resistance of $18.2 \%$ in urinary ESBL-positive E. coli [79], whereas in a study from Spain the prevalence of PMQR genes were found in 28.6\% [80], limiting the activity of quinolones for the treatment of ESBL infections. A systemic review and meta-analysis illustrated that quinolones were not associated with increased mortality regarding empirical therapy and in relation to definitive treatment [32]. Limited data are available regarding the administration of fluoroquinolones as carbapenem-sparing agents. In a study from Taiwan, 299 bacteremia caused by ESBL Enterobacterales indicated a 30-day mortality rate significantly lower in the quinolone group (8.3\%) compared to the carbapenem group $(23 \%)$ [81]. In contrast, imipenem was found superior to quinolone treatment regarding BSI infections caused by ESBL-producing K. pneumoniae [82], whereas in 186 BSI caused by ESBL-PE, a significant predictor of mortality was inadequate initial antimicrobial therapy mainly associated with quinolone treatment [83]. Also, an interesting finding was that inadequately treated patients had a threefold 
increase in mortality compared to the adequately treated group [83]. Quinolones, as an oral option as well as trimethoprim/sulfamethoxazole (as non-intravenous carbapenem-sparing antibiotic) have been implemented as an alternative to carbapenems for bacteremia caused by ESBL. In a 12-year retrospective study from Spain, the use of alternative non-intravenous therapeutic options was associated with shorter hospital stay with no difference in mortality [84]. Therefore, quinolones could be useful as oral switch whenever susceptible; however, the recent FDA warning on quinolones toxicity should be taken under serious consideration [85].

\section{Aminoglycosides}

Aminoglycosides have been shown to be active against Gram-negative bacteria, including ESBL pathogens [86]. In vitro susceptibility rates may vary significantly, depending on the dissemination of aminoglycoside modifying enzymes, which are frequently co-transferred along with other resistance genes on mobile genetic elements. The presence of genes encoding aminoglycoside-modifying enzymes with genes located on integrons or transposons also coding for ESBLs have been reported [87]. Amikacin has been shown to be the most active aminoglycoside against ESBL-PE [88]. The advantageous pharmacokinetic parameter of the aminoglycosides consisting of high urine concentrations, therefore, have been utilized in urinary tract infections as monotherapy $[43,89]$. In the INCREMENT ESBL cohort analysis, empiric treatments with carbapenem-sparing agents (mainly aminoglycosides and fluoroquinolones) versus carbapenem therapy in 86 and 245 patients were included, respectively [90]. No significant differences regarding 30-day mortality between patients treated empirically with carbapenems or aminoglycosides were observed [90]. Even when a stratified analysis was also performed using Kaplan-Meier curves on the low-risk ( $<11$ points) and high-risk $(\geq 11)$ strata of the INCREMENT ESBL score [91], no significant differences on mortality were depicted between the two groups [90]. Similarly, in a retrospective study from Israel, aminoglycoside monotherapy was compared to carbapenem or PTZ for the treatment of ESBL-PE in cUTI associated or not with secondary bacteremia. Aminoglycoside treatment was found non-inferior compared with other antibiotics regarding 30-day mortality; however, non-inferiority for bacteriuria recurrence was observed. An important issue to be mentioned was that patients treated with an aminoglycoside had less severe disease, lower burden of chronic illness and lower incidence of septic shock [92]. In a recent meta-analysis, aminoglycoside treatment was not associated with lower mortality rates regarding empiric and definite treatment compared to carbapenems for the treatment of ESBL-PE bacteremia [32]. Recently, plazomicin, a next-generation aminoglycoside synthetically derived from sisomicin designed to evade all clinically relevant aminoglycoside-modifying enzymes, was launched in market [93]. Plazomicin has been approved by FDA for the treatment of cUTI including acute pyelonephritis [94]. In a phase 3 study, plazomicin was compared to meropenem for the treatment of cUTI. ESBL-PE were present in 57 of 197 patients treated with meropenem and 50 out of 191 treated with plazomicin. Clinical cures at test of cures were $69 \%$ and $72 \%$ respectively [94]. In conclusion, aminoglycosides seem to be an attractive alternative for the treatment of UTIs caused by ESBL-PE (depending on local epidemiology susceptibility patterns).

\section{Tigecycline-Eravacycline-Omadacycline}

Tigecycline, a glycylcycline, is a bacteriostatic derivative of minocycline [72]. It was approved by the FDA and the European Medicines Agency (EMA) in 2005 and 2006, respectively, for the treatment of cIAIs and complicated skin and skin structure infections, and the FDA in 2009 added community-acquired pneumonia to the list. However, nowadays tigecycline is frequently administered off-label for treating MDR infections [43,72]. Tigecycline antimicrobial spectrum includes ESBL-PE, MDR and extensively-drug resistant (XDR) Acinetobacter baumannii and K. pneumoniae [43,72]. From the Tigecycline Evaluation and Surveillance Trial, antimicrobial susceptibility of ESBL-producing E. coli to tigecycline from clinically relevant isolates revealed very low resistance rates below $2 \%$ [95]. Treatment outcomes have been hampered by the low serum concentrations of the drug in the approved dosing 
regimen, the low penetration in the epithelial lining fluid as well as the low concentrations achieved in the urinary system [96]. Tigecycline has been administrated for IAI and soft tissue infections caused by ESBL-producing isolates in non-comparative studies with high clinical cure rates [97,98]. Importantly, both the FDA and the EMA issued warnings because the drug was associated with an increased risk of mortality and clinical failure in meta-analyses of randomized trials [99,100]. Moreover, a basic drawback is a significant number of adverse events (i.e., nausea, vomiting, pancreatitis, hepatotoxicity [72]) as well as more severe ones, consisting of decreased fibrinogen levels and alterations in coagulation parameters [101]. Eravacycline and omadacycline are novel tetracycline derivatives with significant activity against ESBL Gram-negative bacilli [102,103]. Eravacycline has recently been approved by FDA and EMA for adult patients with cIAI [104,105]. In phase 3 with cIAI, participants were randomized to either eravacycline $1 \mathrm{mg} / \mathrm{kg}$ q12 h or meropenem $1 \mathrm{~g} \mathrm{q} 8 \mathrm{~h}$, both given intravenously. In patients with ESBL-PE, clinical cure rates were 88\% (15/17) and 81\% (13/16) in the eravacycline and meropenem groups, respectively [106]. In conclusion, tigecycline is not indicated as a suitable alternative for the treatment of ESBL infections because of several limitations as reported above. However, tigecycline therapy could be appropriate for soft tissue infections and IAI caused by ESBL-PE. Eravacycline is a promising agent for carbapenem-sparing strategies (is available intravenously and also in an oral formula) for the treatment of cIAI caused by ESBL-PE with fewer drawbacks compared to tigecycline. On the other hand, omadacycline could be suitable for soft tissue infections.

\section{Fosfomycin}

Fosfomycin inhibits phosphoenolpyruvate transferase, the first enzyme involved in the synthesis of peptidoglycan. It possesses advantageous pharmacokinetics mainly in the urinary tract system as well as in cerebrospinal fluid, lungs, bone and soft tissue [72]. Fosfomycin is active against a broad spectrum of Gram-positive and Gram-negative bacteria, including ESBL isolates and possesses a low potential for cross resistance with other classes of antibiotics. The relevant available formulation for intravenous administration is fosfomycin disodium. The current recommended intravenous dosage ranges from 16-24 g daily [43,72]. In a review of 11 studies, among 5057 isolates of Enterobacterales, including E. coli (2205 strains) and K. pneumoniae (764 strains), 88\% of which produced ESBL, 91.3\% were found susceptible to fosfomycin [107]. In a real-world perspective and review of the literature of fosfomycin for the treatment of MDR-causing UTIs, patients infected by ESBL-PE demonstrated rates of clinical success of $56 \%$ [108]. The results of a multicenter, randomized, double-blind phase $2 / 3$ trial were announced, showing non-inferiority of intravenous fosfomycin to PTZ, in patients with cUTIs or acute pyelonephritis [109]. The most notable finding of most studies with MDR UTIs treated with fosfomycin monotherapy was the high rates of clinical and microbiologic cure encountered [108,109]. However, no current evidence regarding efficacy of intravenous fosfomycin versus carbapenem is existent. The FOREST trial, a phase 3 clinical trial, has been completed (but not yet analyzed) to prove the non-inferiority of fosfomycin versus meropenem in the targeted treatment of bacteremic UTI due to ESBL-PE, in order to render the elucidation of the true efficacy of intravenous fosfomycin in the era of MDR pathogens [110].

Fosfomycin tromethamine, a soluble salt of fosfomycin, represents the oral formula. Fosfomycin's in vitro activity against common uropathogens, including ESBL isolates, its favorable safety profile, including pregnancy patients, and clinical trial data demonstrating efficacy in cystitis have resulted in recommending fosfomycin as a first line agent for the treatment of acute uncomplicated cystitis [111]. Recently, oral fosfomycin in a unique dosage scheme of $3 \mathrm{~g}$ daily for $1 \mathrm{w}$ followed by $3 \mathrm{~g}$ every $48 \mathrm{~h}$ for a total of 6-12 $\mathrm{w}$ has been promising for the treatment of chronic bacterial prostatitis, including ESBL isolates [112]. Fosfomycin appears as an attractive carbapenem-sparing option mainly for the treatment of cUTI. However, the results of randomized trials are pending to ensure the true efficacy on fosfomycin for the therapy of ESBL UTIs. 


\section{Conclusions}

The established therapeutic option for severe infections caused by ESBL-PE is a carbapenem; however, ertapenem could be an acceptable option in the absence of severe sepsis or resistance. On the other hand, PTZ appears to be a possible option for low- to moderate-severity infection, originating from urinary or biliary sources and when PTZ MIC $\leq 4 \mathrm{mg} / \mathrm{L}$. Ceftolozane-tazobactam appears promising, but further clinical data are needed to establish its efficacy relative to carbapenems. Fosfomycin, aminoglycosides and temocillin are relatively effective for cUTI and could replace carbapenems for the treatment of ESBL-PE. There is little clinical evidence for cephamycin use, which has been associated with development of resistance. Resistance to fluoroquinolones is nowadays common in ESBL-PE. Cefepime may be effective against ESBL-producing organisms that test susceptible (with an MIC $\leq$ $2 \mathrm{mg} / \mathrm{L}$ ) if administered in high doses (i.e., 2 g every $8 \mathrm{~h}$ ); however, it has been associated with increased mortality risk.

Author Contributions: I.K. and H.G. have written and revised the manuscript. All authors have read and agreed to the published version of the manuscript.

Funding: This research received no external funding.

Conflicts of Interest: The authors declare no conflict of interest.

\section{References}

1. Doi, Y.; Iovleva, A.; Bonomo, R.A. The ecology of extended-spectrum $\beta$-lactamases (ESBLs) in the developed world. J. Travel Med. 2017, 2017, S44-S51. [CrossRef]

2. European Center for Disease Prevention and Control (ECDC). Surveillance of Antimicrobial Resistance in Europe 2018; Annual Report of the European Antimicrobial Resistance Surveillance Network (EARS-Net); ECDC: Stockholm, Sweden, 2019; Available online: https:/www.ecdc.europa.eu/en/publications-data/surveillanceantimicrobial-resistance-europe-2018 (accessed on 29 December 2019).

3. Peirano, G.; Pitout, J.D.D. Extended-Spectrum $\beta$-Lactamase-Producing Enterobacteriaceae: Update on Molecular Epidemiology and Treatment Options. Drugs 2019, 2019, 1529-1541. [CrossRef]

4. Maslikowska, J.A.; Walker, S.A.; Elligsen, M.; Mittmann, N.; Palmay, L.; Daneman, N.; Simor, A. Impact of infection with extended-spectrum $\beta$-lactamase-producing Escherichia coli or Klebsiella species on outcome and hospitalization costs. J. Hosp. Infect. 2016, 2016, 33-41. [CrossRef]

5. Rodríguez-Baño, J.; Picón, E.; Gijón, P.; Hernández, J.R.; Ruíz, M.; Peña, C.; Almela, M.; Almirante, B.; Grill, F.; Colomina, J.; et al. Spanish Network for Research in Infectious Diseases (REIPI). Community-onset bacteremia due to extended-spectrum beta-lactamase-producing Escherichia coli: Risk factors and prognosis. Clin. Infect. Dis. 2010, 2010, 40-48. [CrossRef] [PubMed]

6. $\quad$ Kang, C.I.; Wi, Y.M.; Lee, M.Y.; Ko, K.S.; Chung, D.R.; Peck, K.R.; Lee, N.Y.; Song, J.H. Epidemiology and risk factors of community onset infections caused by extended-spectrum $\beta$-lactamase-producing Escherichia coli strains. J. Clin. Microbiol. 2012, 2012, 312-317. [CrossRef] [PubMed]

7. Lee, J.A.; Kang, C.I.; Joo, E.J.; Ha, Y.E.; Kang, S.J.; Park, S.Y.; Chung, D.R.; Peck, K.R.; Ko, K.S.; Lee, N.Y.; et al. Epidemiology and clinical features of community-onset bacteremia caused by extended-spectrum ß-lactamase-producing Klebsiella pneumoniae. Microb. Drug Resist. 2011, 2011, 267-273. [CrossRef] [PubMed]

8. Chong, Y.; Shimoda, S.; Shimono, N. Current epidemiology, genetic evolution and clinical impact of extended-spectrum $\beta$-lactamase-producing Escherichia coli and Klebsiella pneumoniae. Infect. Genet. Evol. 2018, 2018, 185-188. [CrossRef] [PubMed]

9. Vardakas, K.Z.; Tansarli, G.S.; Rafailidis, P.I.; Falagas, M.E. Carbapenems versus alternative antibiotics for the treatment of bacteraemia due to Enterobacteriaceae producing extended-spectrum $\beta$-lactamases: A systematic review and meta-analysis. J. Antimicrob. Chemother. 2012, 67, 2793-2803. [CrossRef] 
10. Rodríguez-Baño, J.; Navarro, M.D.; Retamar, P.; Picón, E.; Pascual, Á. Extended-Spectrum Beta-Lactamases-Red Española de Investigación en Patología Infecciosa/Grupo de Estudio de Infección Hospitalaria Group. $\beta$-Lactam/ $\beta$-lactam inhibitor combinations for the treatment of bacteremia due to extended-spectrum $\beta$-lactamase-producing Escherichia coli: A post hoc analysis of prospective cohorts. Clin. Infect. Dis. 2012, 2012, 167-174. [CrossRef]

11. Ofer-Friedman, H.; Shefler, C.; Sharma, S.; Tirosh, A.; Tal-Jasper, R.; Kandipalli, D.; Sharma, S.; Bathina, P.; Kaplansky, T.; Maskit, M.; et al. Carbapenems Versus Piperacillin-Tazobactam for Bloodstream Infections of Nonurinary Source Caused by Extended-Spectrum Beta-Lactamase-Producing Enterobacteriaceae. Infect. Control Hosp. Epidemiol. 2015, 2015, 981-985. [CrossRef]

12. Harris, P.N.; Yin, M.; Jureen, R.; Chew, J.; Ali, J.; Paynter, S.; Paterson, D.L.; Tambyah, P.A. Comparable outcomes for $\beta$-lactam/ $\beta$-lactamase inhibitor combinations and carbapenems in definitive treatment of bloodstream infections caused by cefotaxime-resistant Escherichia coli or Klebsiella pneumoniae. Antimicrob. Resist. Infect. Control 2015, 2015, 14. [CrossRef] [PubMed]

13. Gutiérrez-Gutiérrez, B.; Pérez-Galera, S.; Salamanca, E.; de Cueto, M.; Calbo, E.; Almirante, B.; Viale, P.; Oliver, A.; Pintado, V.; Gasch, O.; et al. A Multinational, Preregistered Cohort Study of $\beta$-Lactam $/ \beta$-Lactamase Inhibitor Combinations for Treatment of Bloodstream Infections Due to Extended-Spectrum- $\beta$-Lactamase-Producing Enterobacteriaceae. Antimicrob. Agents Chemother. 2016, 2016, 4159-4169. [CrossRef] [PubMed]

14. Viale, P.; Giannella, M.; Bartoletti, M.; Tedeschi, S.; Lewis, R. Considerations About Antimicrobial Stewardship in Settings with Epidemic Extended-Spectrum $\beta$-Lactamase-Producing or Carbapenem-Resistant Enterobacteriaceae. Infect. Dis. Ther. 2015, 4, 65-83. [CrossRef] [PubMed]

15. Gutiérrez-Gutiérrez, B.; Rodríguez-Baño, J. Current options for the treatment of infections due to extended-spectrum beta-lactamase-producing Enterobacteriaceae in different groups of patients. Clin. Microbiol. Infect. 2019, 2019, 932-942. [CrossRef]

16. Rodríguez-Baño, J.; Gutiérrez-Gutiérrez, B.; Machuca, I.; Pascual, A. Treatment of Infections Caused by Extended-Spectrum-Beta-Lactamase-, AmpC-, and Carbapenemase-Producing Enterobacteriaceae. Clin. Microbiol. Rev. 2018, 31, e00079-17. [CrossRef]

17. Aslan, A.T.; Akova, M. Extended spectrum $\beta$-lactamase producing enterobacteriaceae: Carbapenem sparing options. Expert Rev. Anti Infect. Ther. 2019, 2019, 969-981. [CrossRef]

18. Tamma, P.D.; Rodriguez-Bano, J. The Use of Noncarbapenem $\beta$-Lactams for the Treatment of Extended-Spectrum $\beta$-Lactamase Infections. Clin. Infect. Dis. 2017, 2017, 972-980. [CrossRef]

19. Kang, C.I.; Park, S.Y.; Chung, D.R.; Peck, K.R.; Song, J.H. Piperacillin-tazobactam as an initial empirical therapy of bacteremia caused by extended-spectrum $\beta$-lactamase-producing Escherichia coli and Klebsiella pneumoniae. J. Infect. 2012, 2012, 533-534. [CrossRef]

20. Tamma, P.D.; Han, J.H.; Rock, C.; Harris, A.D.; Lautenbach, E.; Hsu, A.J.; Avdic, E.; Cosgrove, S.E.; Antibacterial Resistance Leadership Group. Carbapenem therapy is associated with improved survival compared with piperacillin-tazobactam for patients with extended-spectrum $\beta$-lactamase bacteremia. Clin. Infect. Dis. 2015, 2015, 1319-1325. [CrossRef]

21. Ng, T.M.; Khong, W.X.; Harris, P.N.; De, P.P.; Chow, A.; Tambyah, P.A.; Lye, D.C. Empiric Piperacillin-Tazobactam versus Carbapenems in the Treatment of Bacteraemia Due to Extended-Spectrum Beta-Lactamase-Producing Enterobacteriaceae. PLoS ONE 2016, 2016, e0153696. [CrossRef]

22. Gudiol, C.; Royo-Cebrecos, C.; Abdala, E.; Akova, M.; Álvarez, R.; Maestro-de la Calle, G.; Cano, A.; Cervera, C.; Clemente, W.T.; Martín-Dávila, P.; et al. BICAR Study Group. Efficacy of $\beta$-Lactam $/ \beta$-Lactamase Inhibitor Combinations for the Treatment of Bloodstream Infection Due to Extended-Spectrum- $\beta$-Lactamase-Producing Enterobacteriaceae in Hematological Patients with Neutropenia. Antimicrob. Agents Chemother. 2017, 61, e00164-17. [CrossRef] [PubMed]

23. Seo, Y.B.; Lee, J.; Kim, Y.K.; Lee, S.S.; Lee, J.A.; Kim, H.Y.; Uh, Y.; Kim, H.S.; Song, W. Randomized controlled trial of piperacillin-tazobactam, cefepime and ertapenem for the treatment of urinary tract infection caused by extended-spectrum beta-lactamase-producing Escherichia coli. BMC Infect. Dis. 2017, 2017, 404. [CrossRef] [PubMed]

24. Yoon, Y.K.; Kim, J.H.; Sohn, J.W.; Yang, K.S.; Kim, M.J. Role of piperacillin/tazobactam as a carbapenem-sparing antibiotic for treatment of acute pyelonephritis due to extended-spectrum $\beta$-lactamase-producing Escherichia coli. Int. J. Antimicrob. Agents 2017, 2017, 410-415. [CrossRef] [PubMed] 
25. Ko, J.H.; Lee, N.R.; Joo, E.J.; Moon, S.Y.; Choi, J.K.; Park, D.A.; Peck, K. Appropriate non-carbapenems are not inferior to carbapenems as initial empirical therapy for bacteremia caused by extended-spectrum beta-lactamase-producing Enterobacteriaceae: A propensity score weighted multicenter cohort study. Eur. J. Clin. Microbiol. Infect. Dis. 2018, 37, 305-311. [CrossRef] [PubMed]

26. Harris, P.N.A.; Tambyah, P.A.; Lye, D.C.; Mo, Y.; Lee, T.H.; Yilmaz, M.; Alenazi, T.H.; Arabi, Y.; Falcone, M.; Bassetti, M.; et al. MERINO Trial Investigators and the Australasian Society for Infectious Disease Clinical Research Network (ASID-CRN). JAMA 2018, 320, 984-994. [CrossRef]

27. Benanti, G.E.; Brown, A.R.T.; Shigle, T.L.; Tarrand, J.J.; Bhatti, M.M.; McDaneld, P.M.; Shelburne, S.A.; Aitken, S.L. Carbapenem versus Cefepime or Piperacillin-Tazobactam for Empiric Treatment of Bacteremia Due to Extended-Spectrum- $\beta$-Lactamase-Producing Escherichia coli in Patients with Hematologic Malignancy. Antimicrob. Agents Chemother. 2019, 63, e01813-18. [CrossRef]

28. John, R.; Colley, P.; Nguyen, H.L.; Berhe, M. Outcomes analysis in patients with extended-spectrum beta-lactamase bacteremia empirically treated with piperacillin/tazobactam versus carbapenems. Bayl. Univ. Med. Center Proc. 2019, 2019, 187-191. [CrossRef]

29. Nasir, N.; Ahmed, S.; Razi, S.; Awan, S.; Mahmood, S.F. Risk factors for mortality of patients with ceftriaxone resistant E. coli bacteremia receiving carbapenem versus beta lactam/beta lactamase inhibitor therapy. BMC Res. Notes 2019, 2019, 611. [CrossRef]

30. Sharara, S.L.; Amoah, J.; Pana, Z.D.; Simner, P.J.; Cosgrove, S.E.; Tamma, P.D. Is Piperacillin-Tazobactam Effective for the Treatment of Pyelonephritis Caused by ESBL-producing Organisms? Clin. Infect. Dis. 2019. [CrossRef]

31. López-Cerero, L.; Picón, E.; Morillo, C.; Hernández, J.R.; Docobo, F.; Pachón, J.; Rodríguez-Baño, J.; Pascual, A. Comparative assessment of inoculum effects on the antimicrobial activity of amoxycillin-clavulanate and piperacillin-tazobactam with extended-spectrum beta-lactamase-producing and extended-spectrum beta-lactamase-non-producing Escherichia coli isolates. Clin. Microbiol. Infect. 2010, 2010, 132-136. [CrossRef]

32. Son, S.K.; Lee, N.R.; Ko, J.H.; Choi, J.K.; Moon, S.Y.; Joo, E.J.; Peck, K.R.; Park, D.A. Clinical effectiveness of carbapenems versus alternative antibiotics for treating ESBL-producing Enterobacteriaceae bacteraemia: A systematic review and meta-analysis. J. Antimicrob. Chemother. 2018, 73, 2631-2642. [CrossRef] [PubMed]

33. Sfeir, M.; Askin, G.; Christos, P. Beta-lactam/beta-lactamase inhibitors versus carbapenem for bloodstream infections due to extended-spectrum beta-lactamase-producing Enterobacteriaceae: Systematic review and meta-analysis. Int. J. Antimicrob. Agents 2018, 2018, 554-570. [CrossRef] [PubMed]

34. Thomson, K.S.; Moland, E.S. Cefepime, piperacillin-tazobactam, and the inoculum effect in tests with extended-spectrum beta-lactamase-producing Enterobacteriaceae. Antimicrob. Agents Chemother. 2001, 2001, 3548-3554. [CrossRef] [PubMed]

35. Hayden, M.K.; Won, S.Y. Carbapenem-Sparing Therapy for Extended-Spectrum $\beta$-Lactamase-Producing E coli and Klebsiella pneumoniae Bloodstream Infection: The Search Continues. JAMA 2018, 2018, 979-981. [CrossRef]

36. Giacobbe, D.R.; Bassetti, M.; De Rosa, F.G.; Del Bono, V.; Grossi, P.A.; Menichetti, F.; Pea, F.; Rossolini, G.M.; Tumbarello, M.; Viale, P.; et al. ISGRI-SITA (Italian Study Group on Resistant Infections of the Società Italiana Terapia Antinfettiva). Ceftolozane/tazobactam: Place in therapy. Expert Rev. Anti Infect. Ther. 2018, 2018, 307-320. [CrossRef]

37. Castanheira, M.; Doyle, T.B.; Mendes, R.E.; Sader, H.S. Comparative Activities of Ceftazidime-Avibactam and Ceftolozane-Tazobactam against Enterobacteriaceae Isolates Producing Extended-Spectrum $\beta$-Lactamases from U.S. Hospitals. Antimicrob. Agents Chemother. 2019, 63, e00160-19. [CrossRef]

38. Solomkin, J.; Hershberger, E.; Miller, B.; Popejoy, M.; Friedland, I.; Steenbergen, J.; Yoon, M.; Collins, S.; Yuan, G.; Bare, P.S.; et al. Ceftolozane/Tazobactam Plus Metronidazole for Complicated Intra-abdominal Infections in an Era of Multidrug Resistance: Results From a Randomized, Double-Blind, Phase 3 Trial (ASPECT-cIAI). Clin. Infect. Dis. 2015, 60, 1462-1471. [CrossRef]

39. Wagenlehner, F.M.; Umeh, O.; Steenbergen, J.; Yuan, G.; Darouiche, R.O. Ceftolozane-tazobactam compared with levofloxacin in the treatment of complicated urinary-tract infections, including pyelonephritis: A randomised, double-blind, phase 3 trial (ASPECT-cUTI). Lancet 2015, 385, 1949-1956. [CrossRef] 
40. Kollef, M.H.; Nováček, M.; Kivistik, Ü.; Réa-Neto, Á.; Shime, N.; Martin-Loeches, I.; Timsit, J.F.; Wunderink, R.G.; Bruno, C.J.; Huntington, J.A.; et al. Ceftolozane-tazobactam versus meropenem for treatment of nosocomial pneumonia (ASPECT-NP): A randomised, controlled, double-blind, phase 3, non-inferiority trial. Lancet Infect. Dis. 2019, 19, 1299-1311. [CrossRef]

41. Popejoy, M.W.; Paterson, D.L.; Cloutier, D.; Huntington, J.A.; Miller, B.; Bliss, C.A.; Steenbergen, J.N.; Hershberger, E.; Umeh, O.; Kaye, K.S. Efficacy of ceftolozane/tazobactam against urinary tract andintra-abdominal infections caused by ESBL-producing Escherichia coli and Klebsiella pneumoniae: A pooled analysis of Phase 3 clinical trials. J. Antimicrob. Chemother. 2017, 72, 268-272. [CrossRef]

42. Nguyen, C.P.; Dan Do, T.N.; Bruggemann, R.; Ten Oever, J.; Kolwijck, E.; Adang, E.M.M.; Wertheim, H.F.L. Clinical cure rate and cost-effectiveness of carbapenem-sparing beta-lactams vs. meropenem for Gram-negative infections: A systematic review, meta-analysis, and cost-effectiveness analysis. Int. J. Antimicrob. Agents 2019, 2019, 790-797. [CrossRef] [PubMed]

43. Karaiskos, I.; Lagou, S.; Pontikis, K.; Rapti, V.; Poulakou, G. The "Old" and the "New" Antibiotics for MDR Gram-Negative Pathogens: For Whom, When, and How. Front. Public Health 2019, 2019, 151. [CrossRef] [PubMed]

44. Karaiskos, I.; Galani, I.; Souli, M.; Giamarellou, H. Novel $\beta$-lactam- $\beta$-lactamase inhibitor combinations: Expectations for the treatment of carbapenem-resistant Gram-negative pathogens. Expert Opin. Drug Metab. Toxicol. 2019, 2019, 133-149. [CrossRef] [PubMed]

45. Kazmierczak, K.M.; de Jonge, B.L.M.; Stone, G.G.; Sahm, D.F. In vitro activity of ceftazidime/avibactam against isolates of Pseudomonas aeruginosa collected in European countries: INFORM global surveillance 2012-2015. J. Antimicrob. Chemother. 2018, 2018, 2777-2781. [CrossRef]

46. Mendes, R.; Castanheira, M.; Gasink, L.; Stone, G.G.; Nichols, W.W.; Flamm, R.K.; Jones, R.N. $\beta$-Lactamase Characterization of Gram-Negative Pathogens Recovered from Patients Enrolled in the Phase 2 Trials for Ceftazidime-Avibactam: Clinical Efficacies Analyzed against Subsets of Molecularly Characterized Isolates. Antimicrob. Agents Chemother. 2015, 2015, 1328-1335. [CrossRef]

47. Mendes, R.E.; Castanheira, M.; Woosley, L.N.; Stone, G.G.; Bradford, P.A.; Flamm, R.K. Molecular $\beta$-lactamase characterization of Gram-negative pathogens recovered from patients enrolled in the ceftazidime-avibactam phase 3 trials (RECAPTURE 1 and 2) for complicated urinary tract infections: Efficacies analysed against susceptible and resistant subsets. Int. J. Antimicrob. Agents 2018, 2018, 287-292. [CrossRef]

48. Chastain, D.B.; White, B.P.; Cretella, D.A.; Bland, C.M. Is It Time to Rethink the Notion of Carbapenem-Sparing Therapy Against Extended-Spectrum $\beta$-Lactamase-Producing Enterobacteriaceae Bloodstream Infections? A Critical Review. Ann. Pharmacother. 2018, 2018, 484-492. [CrossRef]

49. Lee, C.H.; Su, L.H.; Tang, Y.F.; Liu, J.W. Treatment of ESBL-producing Klebsiella pneumoniae bacteraemia with carbapenems or flomoxef: A retrospective study and laboratory analysis of the isolates. J. Antimicrob. Chemother. 2006, 2006, 1074-1077. [CrossRef]

50. Yang, C.C.; Li, S.H.; Chuang, F.R.; Chen, C.H.; Lee, C.H.; Chen, J.B.; Wu, C.H.; Lee, C.T. Discrepancy between effects of carbapenems and flomoxef in treating nosocomial hemodialysis access-related bacteremia secondary to extended spectrum beta-lactamase producing Klebsiella pneumoniae in patients on maintenance hemodialysis. BMC Infect. Dis. 2012, 2012, 206. [CrossRef]

51. Doi, A.; Shimada, T.; Harada, S.; Iwata, K.; Kamiya, T. The efficacy of cefmetazole against pyelonephritis caused by extended-spectrum beta-lactamase-producing Enterobacteriaceae. Int. J. Infect. Dis. 2013, 2013, e159-e163. [CrossRef]

52. Pilmis, B.; Parize, P.; Zahar, J.R.; Lortholary, O. Alternatives to carbapenems for infections caused by ESBL-producing Enterobacteriaceae. Eur. J. Clin. Microbiol. Infect. Dis. 2014, 2014, 1263-1265. [CrossRef] [PubMed]

53. Matsumura, Y.; Yamamoto, M.; Nagao, M.; Komori, T.; Fujita, N.; Hayashi, A.; Shimizu, T.; Watanabe, H.; Doi, S.; Tanaka, M.; et al. Multicenter retrospective study of cefmetazole and flomoxef for treatment of extended-spectrum- $\beta$-lactamase-producing Escherichia coli bacteremia. Antimicrob. Agents Chemother. 2015, 2015, 5107-5113. [CrossRef] [PubMed]

54. Lee, C.H.; Su, L.H.; Chen, F.J.; Tang, Y.F.; Li, C.C.; Chien, C.C.; Liu, J.W. Comparative effectiveness of flomoxef versus carbapenems in the treatment of bacteraemia due to extended-spectrum $\beta$-lactamase-producing Escherichia coli or Klebsiella pneumoniae with emphasis on minimum inhibitory concentration of flomoxef: A retrospective study. Int. J. Antimicrob. Agents 2015, 2015, 610-615. [CrossRef] 
55. Fukuchi, T.; Iwata, K.; Kobayashi, S.; Nakamura, T.; Ohji, G. Cefmetazole for bacteremia caused by ESBL-producing enterobacteriaceae comparing with carbapenems. BMC Infect. Dis. 2016, 2016, 427. [CrossRef]

56. Senard, O.; Lafaurie, M.; Lesprit, P.; Nguyen, Y.; Lescure, X.; Therby, A.; Fihman, V.; Oubaya, N.; Lepeule, R. Efficacy of cefoxitin versus carbapenem in febrile male urinary tract infections caused by extended spectrum beta-lactamase-producing Escherichia coli: A multicenter retrospective cohort study with propensity score analysis. Eur. J. Clin. Microbiol. Infect. Dis. 2019. [CrossRef]

57. Endimiani, A.; Perez, F.; Bonomo, R.A. Cefepime: A reappraisal in an era of increasing antimicrobial resistance. Expert Rev. Anti Infect. Ther. 2008, 6, 805-824. [CrossRef]

58. Clinical and Laboratory Standards Institute (CLSI). Performance Standards for Antimicrobial Susceptibility Testing, 29th ed.; CLSI Supplement M100S; Clinical and Laboratory Standards Institute: Wayne, PA, USA, 2019.

59. The European Committee on Antimicrobial Susceptibility Testing (EUCAST). Breakpoint Tables for Interpretation of MICs and Zone Diameters. Version 9.0. 2019. Available online: http://www.eucast.org (accessed on 29 December 2019).

60. Bhat, S.V.; Peleg, A.Y.; Lodise, T.P., Jr.; Shutt, K.A.; Capitano, B.; Potoski, B.A.; Paterson, D.L. Failure of current cefepime breakpoints to predict clinical outcomes of bacteremia caused by gram-negative organisms. Antimicrob. Agents Chemother. 2007, 51, 4390-4395. [CrossRef]

61. Thauvin-Eliopoulos, C.; Tripodi, M.; Moellering, R.C., Jr.; Eliopoulos, G.M. Efficacies of piperacillin-tazobactam and cefepime in rats with experimental intra-abdominal abscesses due to an extended-spectrum beta-lactamase-producing strain of Klebsiella pneumoniae. Antimicrob. Agents Chemother. 1997, 1997, 1053-1057. [CrossRef]

62. Burgess, D.S.; Hall, R.G., 2nd. In vitro killing of parenteral beta-lactams against standard and high inocula of extended-spectrum beta-lactamase and non-ESBL producing Klebsiella pneumoniae. Diagn. Microbiol. Infect. Dis. 2004, 2004, 41-46. [CrossRef]

63. Smith, K.P.; Kirby, J.E. The Inoculum Effect in the Era of Multidrug Resistance: Minor Differences in Inoculum Have Dramatic Effect on MIC Determination. Antimicrob. Agents Chemother. 2018, 62, e00433-18. [CrossRef]

64. Zanetti, G.; Bally, F.; Greub, G.; Garbino, J.; Kinge, T.; Lew, D.; Romand, J.A.; Bille, J.; Aymon, D.; Stratchounski, L.; et al. Cefepime Study Group. Cefepime versus imipenem-cilastatin for treatment of nosocomial pneumonia in intensive care unit patients: A multicenter, evaluator-blind, prospective, randomized study. Antimicrob. Agents Chemother. 2003, 2003, 3442-3447. [CrossRef] [PubMed]

65. Goethaert, K.; Van Looveren, M.; Lammens, C.; Jansens, H.; Baraniak, A.; Gniadkowski, M.; Van Herck, K.; Jorens, P.G.; Demey, H.E.; Ieven, M.; et al. High-dose cefepime as an alternative treatment for infections caused by TEM-24 ESBL-producing Enterobacter aerogenes in severely-ill patients. Clin. Microbiol. Infect. 2006, 2006, 56-62. [CrossRef] [PubMed]

66. Chopra, T.; Marchaim, D.; Veltman, J.; Johnson, P.; Zhao, J.J.; Tansek, R.; Hatahet, D.; Chaudhry, K.; Pogue, J.M.; Rahbar, H.; et al. Impact of cefepime therapy on mortality among patients with bloodstream infections caused by extended-spectrum- $\beta$-lactamase-producing Klebsiella pneumoniae and Escherichia coli. Antimicrob. Agents Chemother. 2012, 2012, 3936-3942. [CrossRef] [PubMed]

67. Lee, N.Y.; Lee, C.C.; Huang, W.H.; Tsui, K.C.; Hsueh, P.R.; Ko, W.C. Cefepime therapy for monomicrobial bacteremia caused by cefepime-susceptible extended-spectrum beta-lactamase-producing Enterobacteriaceae: MIC matters. Clin. Infect. Dis. 2013, 2013, 488-495. [CrossRef]

68. Wang, R.; Cosgrove, S.E.; Tschudin-Sutter, S.; Han, J.H.; Turnbull, A.E.; Hsu, A.J.; Avdic, E.; Carroll, K.C.; Tamma, P.D. Cefepime Therapy for Cefepime-Susceptible Extended-Spectrum $\beta$-Lactamase-Producing Enterobacteriaceae Bacteremia. Open Forum Infect. Dis. 2016, 2016, ofw132. [CrossRef]

69. Lee, N.Y.; Lee, C.C.; Li, C.W.; Li, M.C.; Chen, P.L.; Chang, C.M.; Ko, W.C. Cefepime Therapy for Monomicrobial Enterobacter cloacae Bacteremia: Unfavorable Outcomes in Patients Infected by Cefepime-Susceptible Dose-Dependent Isolates. Antimicrob. Agents Chemother. 2015, 2015, 7558-7563. [CrossRef]

70. Suh, J.W.; Yang, K.S.; Kim, S.B.; Kim, J.H.; Sohn, J.W.; Kim, M.J.; Yoon, Y.K. The use of cefepime as a carbapenem-sparing antibiotic for treating uncomplicated acute pyelonephritis caused by extended-spectrum $\beta$-lactamase producing Escherichia coli. Infect. Dis. 2018, 2018, 241-244. [CrossRef] 
71. Kim, S.; Altshuler, J.; Paris, D.; Fedorenko, M. Cefepime versus carbapenems for the treatment of urinary tract infections caused by extended-spectrum $\beta$-lactamase-producing enterobacteriaceae. Int. J. Antimicrob. Agents 2018, 2018, 155-158. [CrossRef]

72. Karaiskos, I.; Giamarellou, H. Multidrug-resistant and extensively drug-resistant Gram-negative pathogens: Current and emerging therapeutic approaches. Expert Opin. Pharmacother. 2014, 2014, 1351-1370. [CrossRef]

73. Duployez, C.; Loïez, C.; Cattoen, C.; Wallet, F.; Vachée, A. In vitro activity of temocillin against extended-spectrum beta-lactamase-producing Escherichia coli and Klebsiella pneumoniae strains isolated from urinary tract infections in France. Med. Mal. Infect. 2019, 2019, 47-53. [CrossRef]

74. Alexandre, K.; Réveillon-Istin, M.; Fabre, R.; Delbos, V.; Etienne, M.; Pestel-Caron, M.; Dahyot, S.; Caron, F. Temocillin against Enterobacteriaceae isolates from community-acquired urinary tract infections: Low rate of resistance and good accuracy of routine susceptibility testing methods. J. Antimicrob. Chemother. 2018, 2018, 1848-1853. [CrossRef] [PubMed]

75. Balakrishnan, I.; Awad-El-Kariem, F.M.; Aali, A.; Kumari, P.; Mulla, R.; Tan, B.; Brudney, D.; Ladenheim, D.; Ghazy, A.; Khan, I.; et al. Temocillin use in England: Clinical and microbiological efficacies in infections caused by extended-spectrum and/or derepressed AmpC $\beta$-lactamase-producing Enterobacteriaceae. J. Antimicrob. Chemother. 2011, 2011, 2628-2631. [CrossRef] [PubMed]

76. Laterre, P.F.; Wittebole, X.; Van de Velde, S.; Muller, A.E.; Mouton, J.W.; Carryn, S.; Tulkens, P.M.; Dugernier, T. Temocillin ( $6 \mathrm{~g}$ daily) in critically ill patients: Continuous infusion versus three times daily administration. J. Antimicrob. Chemother. 2015, 2015, 891-898. [CrossRef]

77. Woerther, P.L.; Lepeule, R.; Burdet, C.; Decousser, J.W.; Ruppé, É.; Barbier, F. Carbapenems and alternative $\beta$-lactams for the treatment of infections due to extended-spectrum $\beta$-lactamase-producing Enterobacteriaceae: What impact on intestinal colonisation resistance? Int. J. Antimicrob. Agents 2018, 2018, 762-770. [CrossRef]

78. Rodríguez-Martínez, J.M.; Machuca, J.; Cano, M.E.; Calvo, J.; Martínez-Martínez, L.; Pascual, A. Plasmid-mediated quinolone resistance: Two decades on. Drug Resist. Updat. 2016, 2016, 13-29. [CrossRef]

79. Karlowsky, J.A.; Lagacé-Wiens, P.R.S.; Adam, H.J.; Baxter, M.R.; Laing, N.M.; Walkty, A.J.; Zhanel, G.G. In vitro susceptibility of urinary Escherichia coli isolates to first- and second-line empirically prescribed oral antimicrobials: Canward surveillance study results for Canadian outpatients, 2007-2016. Int. J. Antimicrob. Agents 2019, 2019, 62-68. [CrossRef]

80. Albert, M.; Yagüe, G.; Fernández, M.; Viñuela, L.; Segovia, M.; Muñoz, J.L. Prevalence of plasmid-mediated quinolone resistance determinants in extended-spectrum $\beta$-lactamase-producing and -non-producing enterobacteria in Spain. Int. J. Antimicrob. Agents 2014, 43, 390-391. [CrossRef]

81. Lo, C.L.; Lee, C.C.; Li, C.W.; Li, M.C.; Hsueh, P.R.; Lee, N.Y.; Ko, W.C. Fluoroquinolone therapy for bloodstream infections caused by extended-spectrum beta-lactamase-producing Escherichia coli and Klebsiella pneumoniae. Microbiol. Immunol. Infect. 2017, 2017, 355-361. [CrossRef]

82. Endimiani, A.; Luzzaro, F.; Perilli, M.; Lombardi, G.; Colì, A.; Tamborini, A.; Amicosante, G.; Toniolo, A. Bacteremia due to Klebsiella pneumoniae isolates producing the TEM-52 extended-spectrum beta-lactamase: Treatment outcome of patients receiving imipenem or ciprofloxacin. Clin. Infect. Dis. 2004, 2004, 243-251. [CrossRef]

83. Tumbarello, M.; Sanguinetti, M.; Montuori, E.; Trecarichi, E.M.; Posteraro, B.; Fiori, B.; Citton, R.; D’Inzeo, T.; Fadda, G.; Cauda, R.; et al. Predictors of mortality in patients with bloodstream infections caused by extended-spectrum-beta-lactamase-producing Enterobacteriaceae: Importance of inadequate initial antimicrobial treatment. Antimicrob. Agents Chemother. 2007, 2007, 1987-1994. [CrossRef]

84. Meije, Y.; Pigrau, C.; Fernández-Hidalgo, N.; Clemente, M.; Ortega, L.; Sanz, X.; Loureiro-Amigo, J.; Sierra, M.; Ayestarán, A.; Morales-Cartagena, A.; et al. Non-intravenous carbapenem-sparing antibiotics for definitive treatment of bacteraemia due to Enterobacteriaceae producing extended-spectrum $\beta$-lactamase (ESBL) or AmpC $\beta$-lactamase: A propensity score study. Int. J. Antimicrob. Agents 2019, 54, 189-196. [CrossRef] [PubMed]

85. U.S. Food and Drug Administration (FDA). FDA Updates Warnings for Fluoroquinolone Antibiotics on Risks of Mental Health and Low Blood Sugar Adverse Reactions. Available online: https://www.fda.gov/news-events/press-announcements/fda-updates-warnings-fluoroquinoloneantibiotics-risks-mental-health-and-low-blood-sugar-adverse (accessed on 29 December 2019). 
86. Sutherland, C.A.; Verastegui, J.E.; Nicolau, D.P. In vitro potency of amikacin and comparators against E. coli, K. pneumoniae and P. aeruginosa respiratory and blood isolates. Ann. Clin. Microbiol. Antimicrob. 2016, 15, 39. [CrossRef]

87. Fernández-Martínez, M.; Ruiz Del Castillo, B.; Lecea-Cuello, M.J.; Rodríguez-Baño, J.; Pascual, Á.; Martínez-Martínez, L. Spanish Network for the Research in Infectious Diseases (REIPI) and the Spanish Group for Nosocomial Infections (GEIH). Prevalence of Aminoglycoside-Modifying Enzymes in Escherichia coli and Klebsiella pneumoniae Producing Extended Spectrum $\beta$-Lactamases Collected in Two Multicenter Studies in Spain. Microb. Drug Resist. 2018, 2018, 367-376. [CrossRef]

88. Bouxom, H.; Fournier, D.; Bouiller, K.; Hocquet, D.; Bertrand, X. Which non-carbapenem antibiotics are active against extended-spectrum $\beta$-lactamase-producing Enterobacteriaceae? Int. J. Antimicrob. Agents 2018, 2018, 100-103. [CrossRef] [PubMed]

89. Vidal, L.; Gafter-Gvili, A.; Borok, S.; Fraser, A.; Leibovici, L.; Paul, M. Efficacy and safety of aminoglycoside monotherapy: Systematic review and meta-analysis of randomized controlled trials. J. Antimicrob. Chemother. 2007, 2007, 247-257. [CrossRef]

90. Palacios-Baena, Z.R.; Gutiérrez-Gutiérrez, B.; Calbo, E.; Almirante, B.; Viale, P.; Oliver, A.; Pintado, V.; Gasch, O.; Martínez-Martínez, L.; Pitout, J.; et al. Spanish Network for Research in Infectious Diseases (REIPI)/European Study Group of Bloodstream Infections and Sepsis (ESGBIS)/INCREMENT Group. Empiric Therapy with Carbapenem-Sparing Regimens for Bloodstream Infections due to Extended-Spectrum $\beta$-Lactamase-Producing Enterobacteriaceae: Results from the Increment Cohort. Clin. Infect. Dis. 2017, 2017, 1615-1623. [CrossRef]

91. Palacios-Baena, Z.R.; Gutiérrez-Gutiérrez, B.; De Cueto, M.; Viale, P.; Venditti, M.; Hernández-Torres, A.; Oliver, A.; Martínez-Martínez, L.; Calbo, E.; Pintado, V.; et al. Reipi/Esgbis/Increment Group. Development and validation of the INCREMENT-ESBL predictive score for mortality in patients with bloodstream infections due to extended-spectrum- $\beta$-lactamase-producing Enterobacteriaceae. J. Antimicrob. Chemother. 2017, 2017, 906-913. [CrossRef]

92. Zohar, I.; Schwartz, O.; Yossepowitch, O.; David, S.S.B.; Maor, Y. Aminoglycoside versus carbapenem or piperacillin/tazobactam treatment for bloodstream infections of urinary source caused by Gram-negative ESBL-producing Enterobacteriaceae. J. Antimicrob. Chemother. 2019. [CrossRef]

93. Karaiskos, I.; Souli, M.; Giamarellou, H. Plazomicin: An investigational therapy for the treatment of urinary tract infections. Expert Opin. Investig. Drugs 2015, 2015, 1501-1511. [CrossRef]

94. U.S. Food and Drug Administration (FDA). Drug Approval Package: Zemdri (Plazomicin). Available online: https://www.accessdata.fda.gov/drugsatfda_docs/nda/2018/210303Orig1s000MedR.pdf (accessed on 29 December 2019).

95. Rodloff, A.C.; Dowzicky, M.J. Chemotherapy. Antimicrobial Susceptibility among European Gram-Negative and Gram-Positive Isolates Collected as Part of the Tigecycline Evaluation and Surveillance Trial (2004-2014). Chemotherapy 2017, 2017, 1-11. [CrossRef]

96. Giamarellou, H.; Poulakou, G. Pharmacokinetic and pharmacodynamic evaluation of tigecycline. Expert Opin. Drug Metab. Toxicol. 2011, 2011, 1459-1470. [CrossRef] [PubMed]

97. Heizmann, W.R.; Löschmann, P.A.; Eckmann, C.; von Eiff, C.; Bodmann, K.F.; Petrik, C. Clinical efficacy of tigecycline used as monotherapy or in combination regimens for complicated infections with documented involvement of multiresistant bacteria. Infection 2015, 2015, 37-43. [CrossRef] [PubMed]

98. Poulakou, G.; Kontopidou, F.V.; Paramythiotou, E.; Kompoti, M.; Katsiari, M.; Mainas, E.; Nicolaou, C.; Yphantis, D.; Antoniadou, A.; Trikka-Graphakos, E.; et al. Tigecycline in the treatment of infections from multi-drug resistant gram-negative pathogens. J. Infect. 2009, 2009, 273-284. [CrossRef] [PubMed]

99. Tasina, E.; Haidich, A.B.; Kokkali, S.; Arvanitidou, M. Efficacy and safety of tigecycline for the treatment of infectious diseases: A meta-analysis. Lancet Infect. Dis. 2011, 2011, 834-844. [CrossRef]

100. Shen, F.; Han, Q.; Xie, D.; Fang, M.; Zeng, H.; Deng, Y. Efficacy and safety of tigecycline for the treatment of severe infectious diseases: An updated meta-analysis of RCTs. Int. J. Infect. Dis. 2015, 2015, 25-33. [CrossRef]

101. Routsi, C.; Kokkoris, S.; Douka, E.; Ekonomidou, F.; Karaiskos, I.; Giamarellou, H. High-dose tigecycline-associated alterations in coagulation parameters in critically ill patients with severe infections. Int. J. Antimicrob. Agents 2015, 2015, 90-93. [CrossRef] 
102. Huband, M.D.; Pfaller, M.A.; Shortridge, D.; Flamm, R.K. Surveillance of omadacycline activity tested against clinical isolates from the United States and Europe: Results from the SENTRY Antimicrobial Surveillance Programme, 2017. J. Glob. Antimicrob. Resist. 2019, 2019, 56-63. [CrossRef]

103. Morrissey, I.; Olesky, M.; Hawser, S.; Lob, S.H.; Karlowsky, J.A.; Corey, G.R.; Bassetti, M.; Fyfe, C. In Vitro Activity of Eravacycline against Gram-Negative Bacilli Isolated in Clinical Laboratories Worldwide from 2013 to 2017. Antimicrob. Agents Chemother. 2019. [CrossRef]

104. U.S. Food and Drug Administration (FDA). Drug Approval Package: XERAVA (Eravacycline). Available online: https://www.accessdata.fda.gov/drugsatfda_docs/nda/2018/211109Orig1s000TOC.cfm (accessed on 29 December 2019).

105. European Medicines Agency (EMA). XERAVA (Eravacycline). Available online: https://www.ema.europa. eu/en/medicines/human/EPAR/xerava (accessed on 29 December 2019).

106. Solomkin, J.S.; Gardovskis, J.; Lawrence, K.; Montravers, P.; Sway, A.; Evans, D.; Tsai, L. IGNITE4: Results of a Phase 3, Randomized, Multicenter, Prospective Trial of Eravacycline vs Meropenem in the Treatment of Complicated Intraabdominal Infections. Clin. Infect. Dis. 2019, 2019, 921-929. [CrossRef]

107. Falagas, M.E.; Kastoris, A.C.; Kapaskelis, A.M.; Karageorgopoulos, D.E. Fosfomycin for the treatment of multidrug-resistant, including extended-spectrum beta-lactamase producing, Enterobacteriaceae infections: A systematic review. Lancet Infect. Dis. 2010, 2010, 43-50. [CrossRef]

108. Babiker, A.; Clarke, L.; Doi, Y.; Shields, R.K. Fosfomycin for treatment of multidrug-resistant pathogens causing urinary tract infection: A real-world perspective and review of the literature. Diagn. Microbiol. Infect. Dis. 2019, 2019, 114856. [CrossRef] [PubMed]

109. Kaye, K.S.; Rice, L.B.; Dane, A.L.; Stus, V.; Sagan, O.; Fedosiuk, E.; Das, A.F.; Skarinsky, D.; Eckburg, P.B.; Ellis-Grosse, E.J. Fosfomycin for Injection (ZTI-01) Versus Piperacillin-tazobactam for the Treatment of Complicated Urinary Tract Infection Including Acute Pyelonephritis: ZEUS, A Phase 2/3 Randomized Trial. Clin. Infect. Dis. 2019, 2019, 2045-2056. [CrossRef] [PubMed]

110. Rosso-Fernández, C.; Sojo-Dorado, J.; Barriga, A.; Lavín-Alconero, L.; Palacios, Z.; López-Hernández, I.; Merino, V.; Camean, M.; Pascual, A.; Rodríguez-Baño, J. Forest Study Group. Fosfomycin versus meropenem in bacteraemic urinary tract infections caused by extended-spectrum $\beta$-lactamase-producing Escherichia coli (FOREST): Study protocol for an investigator-driven randomised controlled trial. BMJ Open 2015, 2015, e007363. [CrossRef]

111. Zhanel, G.G.; Walkty, A.J.; Karlowsky, J.A. Fosfomycin: A First-Line Oral Therapy for Acute Uncomplicated Cystitis. Can. J. Infect. Dis. Med. Microbiol. 2016, 2016, 2082693. [CrossRef] [PubMed]

112. Karaiskos, I.; Galani, L.; Sakka, V.; Gkoufa, A.; Sopilidis, O.; Chalikopoulos, D.; Alivizatos, G.; Giamarellou, E. Oral fosfomycin for the treatment of chronic bacterial prostatitis. J. Antimicrob. Chemother. 2019, 2019, 1430-1437. [CrossRef]

(C) 2020 by the authors. Licensee MDPI, Basel, Switzerland. This article is an open access article distributed under the terms and conditions of the Creative Commons Attribution (CC BY) license (http://creativecommons.org/licenses/by/4.0/). 